\title{
Mesenchymal stem cell derived-exosomes: a modern approach in translational medicine
}

\author{
Sepideh Nikfarjam¹ , Jafar Rezaie ${ }^{2}$, Naime Majidi Zolbanin ${ }^{3}$ and Reza Jafari2 ${ }^{*}$ (i)
}

\begin{abstract}
Mesenchymal stem cells (MSCs) have captured great attention in regenerative medicine for over a few decades by virtue of their differentiation capacity, potent immunomodulatory properties, and their ability to be favorably cultured and manipulated. Recent investigations implied that the pleiotropic effects of MSCs is not associated to their ability of differentiation, but rather is mediated by the secretion of soluble paracrine factors. Exosomes, nanoscale extracellular vesicles, are one of these paracrine mediators. Exosomes transfer functional cargos like miRNA and mRNA molecules, peptides, proteins, cytokines and lipids from MSCs to the recipient cells. Exosomes participate in intercellular communication events and contribute to the healing of injured or diseased tissues and organs. Studies reported that exosomes alone are responsible for the therapeutic effects of MSCs in numerous experimental models. Therefore, MSC-derived exosomes can be manipulated and applied to establish a novel cell-free therapeutic approach for treatment of a variety of diseases including heart, kidney, liver, immune and neurological diseases, and cutaneous wound healing. In comparison with their donor cells, MSC-derived exosomes offer more stable entities and diminished safety risks regarding the administration of live cells, e.g. microvasculature occlusion risk. This review discusses the exosome isolation methods invented and utilized in the clinical setting thus far and presents a summary of current information on MSC exosomes in translational medicine.
\end{abstract}

Keywords: Mesenchymal stem cell, Exosome, Extracellular vesicle, Exosome isolation, Regenerative medicine

\section{Background}

Mesenchymal stem/stromal cells (MSCs) are multipotent nonhematopoietic adult cells initially discovered by Alexander Friedenstein while studying the bone marrow. MSCs, possibly originated from the mesoderm, were reported to express CD73, CD90 and CD105 plasma membrane markers while not expressing CD14, CD34 and CD45 molecules [1, 2]. In addition to the bone marrow, MSCs can be isolated from other adult tissues including adipose tissue, amniotic fluid, dental pulp, placenta, umbilical cord blood, Wharton's jelly and even the brain, kidney, liver, lung, spleen, pancreas and thymus

\footnotetext{
*Correspondence: Jafari.reza@umsu.ac.ir

${ }^{2}$ Solid Tumor Research Center, Cellular and Molecular Medicine Research Institute, Urmia University of Medical Sciences, Shafa St, Ershad Blvd, P.O. BoX: 1138, 57147 Urmia, Iran

Full list of author information is available at the end of the article
}

[1, 3]. MSCs are known for their ability of differentiation, self-renewal and colony formation [4]. The unique capacity of MSCs to proliferate in vitro and differentiate into various cellular phenotypes represented a great opportunity for their recruitment as therapeutic agents to heal necrotic or apoptotic cells of the connective tissue. In fact, MSCs can differentiate into different lineages of mesenchymal origin including adipocytes, endothelial cells, cardiomyocytes, chondrocytes and osteoblasts as well as numerous nonmesenchymal lineages such as hepatocytes and neuron-like cells $[5,6]$. The differentiation of MSCs into functional nonmesodermal cells casted doubt on the conventional paradigm that adult stem cells only differentiate from their corresponding germ layer [7]. While subsequent investigations attributed this cross-germ line differentiation to cell fusion events or methodology limitations $[8,9]$, the mechanism of tissue

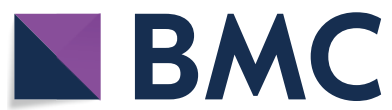

(c) The Author(s) 2020. This article is licensed under a Creative Commons Attribution 4.0 International License, which permits use, sharing, adaptation, distribution and reproduction in any medium or format, as long as you give appropriate credit to the original author(s) and the source, provide a link to the Creative Commons licence, and indicate if changes were made. The images or other third party material in this article are included in the article's Creative Commons licence, unless indicated otherwise in a credit line to the material. If material is not included in the article's Creative Commons licence and your intended use is not permitted by statutory regulation or exceeds the permitted use, you will need to obtain permission directly from the copyright holder. To view a copy of this licence, visit http://creativecommons.org/licenses/by/4.0/. The Creative Commons Public Domain Dedication waiver (http://creativecommons.org/publicdomain/zero/1.0/) applies to the data made available in this article, unless otherwise stated in a credit line to the data. 
repair by MSCs particularly in nonmesodermal tissues remained to be unraveled.

It was originally assumed that upon in vivo injection, MSCs start to regenerate the damaged/diseased sites by travelling to the respective locations, engraftment, and subsequent differentiation into mature functional cells. However, this classic hypothesis was later challenged by findings from numerous animal and human studies performed during the last decades. To our surprise, it was demonstrated that MSCs neither engraft in large quantities nor for time spans long enough to explain the tissue replacement process [10]. According to a more contemporary hypothesis, MSCs employ alternate modes of tissue repair and affect their neighboring cells by inducing cell viability, proliferation and differentiation, decreasing cell apoptosis and fibrosis, stimulating extracellular matrix remodeling, and sometimes adjusting the local immune system responses to inhibit inflammation. These alternate strategies involve paracrine signaling between MSCs and the adjacent cells, which is facilitated by producing and releasing certain trophic factors, cytokines, chemokines and hormones, intercellular interactions facilitated by tunneling nanotubes, and secreting extracellular vesicles (EVs) like exosomes [3]. Exosomes derived from MSCs represent biological functions similar to these cells by contributing to tissue regeneration through enclosing and conveying active biomolecules such as peptides, proteins and RNA species to the diseased cells/tissues [11]. In this article, we overview current available exosome isolation methods intended for therapeutic application, and then summarize recent important achievements regarding the therapeutic implementation of MSC-derived exosomes in regenerative medicine in both experimental models and clinical trials.

\section{Exosomes}

Exosomes (30-150 $\mathrm{nm}$ in diameter) are classified as one of the three subpopulations of EVs. The other two subpopulations include microvesicles/shedding particles and apoptotic bodies (both larger than $100 \mathrm{~nm}$ ). Exosomes are formed by sprouting as intraluminal vesicles (ILVs) within the luminal space of late endosomes or so-called multivesicular bodies (MVBs) [12]. The ILVs are then secreted as exosomes once MVBs incorporate to the cellular membrane. Exosomes were initially detected by Rose Johnstone and colleagues in 1983 as the vesicles involved in mammalian reticulocyte differentiation and maturation [13]. Johnstone selected the term "exosome" because "the process seemed to be akin to reverse endocytosis, with internal vesicular contents released in contrast to external molecules internalized in membranebound structures" [14, 15]. Exosomes are constantly produced and released by numerous haematopoietic and nonhaematopoietic cell types including reticulocytes, B and $\mathrm{T}$ lymphocytes, platelets, mast cells, intestinal epithelial cells, dendritic cells, neoplastic cell lines, and the immune cells of the nervous system, i.e. microglia and neurons [16-18]. Accumulating knowledge has revealed that exosomes play significant role in a variety of cellto-cell interaction pathways associated with numerous physiological and pathological functions.

According to their molecular composition and morphology, there are different populations of MVBs and thus different populations of exosomes within a cell. However, not all MVBs are destined for extracellular release. For instance, it was shown that only MVBs containing higher proportion of cholesterol could fuse with the cellular membrane of B lymphocytes and secrete exosomes [19]. More interestingly, multiple researches have shown that exosomes secreted from the apical and basolateral sides of polarized cells have different molecular compositions [20]. However, the content of exosomes partly reflects the content of their parent cells [21]. Exosomes contain a wide variety of cytoplasmic and membrane proteins including receptors, enzymes, transcription factors, extracellular matrix proteins, nucleic acids (mtDNA, ssDNA, dsDNA, mRNA and miRNA) and lipids [18]. Investigations of the exosomal protein content have revealed that some of these proteins are restricted to certain cell/tissue types, but others are common among all exosomes. While cell adhesion molecules (CAMs), integrins, tetraspanins and major histocompatibility complex (MHC) I/II proteins are common amongst all exosomes, a number of fusion and transferring proteins like Rab2, Rab7, annexins, flotillin, heat shock and cytoskeleton proteins, and MVB-generating proteins like Alix (ALG2-interacting protein $\mathrm{X}$ ) are considered nonspecific exosomal proteins [22, 23].

Unlike proteins, exosomal lipid content is usually conserved and cell type-specific. Lipids play pivotal roles in forming and protecting exosomal structure, vesicle biogenesis and regulation of homeostasis in their target cells [24]. For instance, enhanced concentrations of lysobisphosphatidic acid in the inner phospholipid layer of MVB membrane in cooperation with Alix enable inward sprouting of MVBs and thereby exosome formation [25]. Exosomes also regulate the homeostasis of their target cells by altering their lipid composition particularly in cholesterol and sphingomyelin [25].

\section{Methods of exosome isolation for therapeutic application}

In the following section, we will discuss the two most frequently utilized methods, i.e. ultracentrifugation (UC)-based techniques and ultrafiltration (UF), for isolation of exosomes for therapeutic application. Schematic 
representation of the isolation methods is depicted in Fig. 1 and both methods are compared in detail in Table 1.

\section{Ultracentrifugation-based techniques}

When a suspension is centrifuged, its constituents will be separated on the basis of their physical features such as size, shape and density, the exerted centrifugal force, and the viscosity of the solvent. In ultracentrifugation (UC), extremely high centrifugal forces (up to $1,000,000 \mathrm{~g}$ ) are applied to particulate components of a sample. UC methods are generally divided into analytical and preparative techniques. In the field of exosome isolation, preparative UC methods are considered the gold standard and account for approximately $56 \%$ of all methods employed by researchers [26]. In the following section, we will discuss two types of common preparative UC-based approaches for isolation of exosomes.

Differential ultracentrifugation The successive steps of centrifugation and debris removal is referred to as differential ultracentrifugation (DUC), which is the first and still most frequent method implemented for isolation of EVs. Prior to isolation, sample is cleaned from large biocomponents and protease inhibitors are used to prevent degradation of exosomal proteins [27]. DUC consists of two to three successive low-speed (500 g) centrifugation steps to pellet out cells, microvesicles and other particles of the extracellular matrix. Further purification is then performed by 0.22 microfiltration and elimination of apoptotic bodies through centrifugation at $10,000 \mathrm{~g}$. Finally, exosomes are retrieved by UC at approximately $100,000-120,000 \mathrm{~g}$ for $60-120 \mathrm{~min}$ and subsequent washing in a proper medium like phosphate buffered saline (PBS) [28]. Since the size and density of most EVs and other cellular components overlap to some extent, DUC does not yield pure exosomes, but rather results in an enrichment of exosomes. In fact, the final preparation is somewhat low in exosome recovery and often includes other particles such as serum lipoparticles [29]. If the secretory autophagy pathway is induced, lipid droplets originated from autophagosomes can also be co-isolated with exosomes [30]. The presence of large quantities of cholesteryl ester or triacylglycerol in the final preparation is defined as an index of impurity which is caused by lipoproteins or lipid droplets [31]. Therefore, it was proposed that the outcome of the $100,000 \mathrm{~g}$ pellet should be considered "small EVs", not 'exosomes' [32]. In an attempt to increase the exosomal yield obtained by DUC, UC duration was increased to $4 \mathrm{~h}$ which led to serious physical damage to the exosomes, not to mention the higher contamination levels of soluble proteins [33]. DUC is laborious and time-consuming, however, it is generally applicable to large sample volumes [34], making its scalability feasible for clinical purposes [29]. Another drawback of DUC method is that its outcome is restricted by rotor capacity. Nevertheless, DUC technique requires little methodological expertise and almost no sample pretreatment [33]. Additionally, DUC is cost-effective over time and is widely utilized for isolation of exosomes in the clinical setting [35-38].

Density gradient ultracentrifugation In density gradient ultracentrifugation (DGUC), a density gradient is usually constructed using iodoxinol, $\mathrm{CsCl}$, or sucrose in a centrifuge tube before the separation takes place [39]. DGUC was reported to efficiently separate exosomes from soluble cellular components and protein aggregates, and resulted in the purest exosome recovery in comparison with DUC and precipitation-based techniques [40]. DGUC methods generally include rate-zonal ultracentrifugation and isopycnic ultracentrifugation. Several investigations have combined DGUC methods with DUC and reported that the purity of the separated exosomes were

\footnotetext{
(See figure on next page.)

Fig. 1 Schematic representation of most frequently utilized exosome isolation methods for therapeutic purpose. a Differential ultracentrifugation (DUC): Sample is subjected to 2-3 steps of low-speed (500 g) centrifugation to pellet out cells, microvesicles (MVs), extracellular matrix (ECM) components, and cellular debris. The supernatant is then centrifuged at 10,000 $\mathrm{g}$ for removal of apoptotic bodies (ABs) and contaminating proteins. Finally, exosomes are retrievd by a long (60-120 min) ultracentrifugation (UC) step at 100,000-200,000 g and subsequent washing of the pellet in PBS; $\mathbf{b}$ rate-zonal ultracentrifugation (RZUC): RZUC is a type of density gradient UC (DGUC) where sample is placed at the surface of a gradient density medium such as sucrose, and following a step of UC at 100,000 g, sample components migrate through the gradient density and separate according to their size and shape; $\mathbf{c}$ isopycnic ultracentrifugation (IPUC): IPUC is another type of DGUC that separates particles based on their density. Sample is usually mixed with a self-generating gradient substance such as $\mathrm{CsCl}$, and is then subjected to a long UC step. In the end, distributed components form bands, so-called the isopycnic position, where the buoyant density of the collected particles matches with the gradient density of the surrounding solution. The banded exosomes can be retrieved from the density zone between $1.10 \mathrm{and} 1.21 \mathrm{~g} / \mathrm{mL}$ by fractionation; $\mathbf{d}$ sequential filtration (SF): Sample is first subjected to a 100-nm dead-end (normal) filteration process to separate cells and larger particles. Then, contaminating proteins are excluded via tangential flow filtration using a 500-kDa MWCO membrane. Lastly, the filtrate is once more passed through a track-etch membrane filter (with pore size of $100 \mathrm{~nm}$ ) at very low pressure in order to inhibit passing of flexible nonexosomal EVs into the filtrate while allowing for passage of exosomes
} 


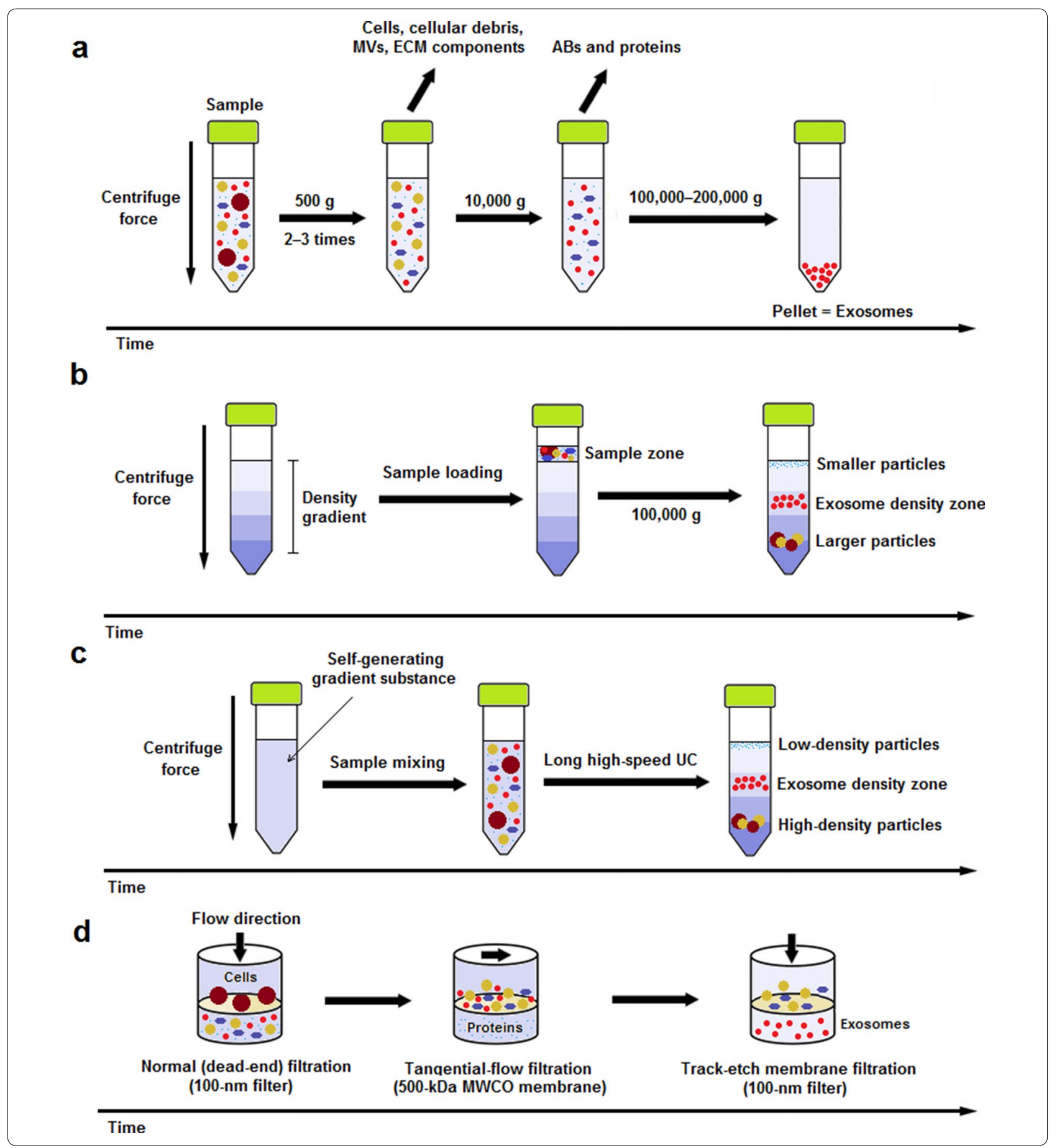

drastically improved. However, the gradient construction in this strategy was extremely time-consuming and further precaution was required to inhibit the gradient damage during acceleration and deceleration step [28]. DGUC usually leads to a relatively low exosomal yield and is not capable of discriminating different populations of EVs [32], which generally limits its application to large-scale exosome preparation for clinical purposes [41]. Nevertheless, several studies have successfully combined sucrose/ deuterium oxide $\left(\mathrm{D}_{2} \mathrm{O}\right)$ DGUC with $\mathrm{UC}$ for isolation of exosomes for clinical use [42, 43].

Rate-zonal ultracentrifugation: In rate-zonal ultracentrifugation (RZUC), the sample is located in a thin zone at the surface of a shallow gradient density medium, 
Table 1 Comparison of two most frequently utilized exosome isolation methods for clinical utility

\begin{tabular}{|c|c|c|}
\hline & DUC & UF \\
\hline Mechanism of exosome separation & $\begin{array}{l}\text { Physical features of exosomes (size, shape and density), the exerted } \\
\text { centrifugal force, and the viscosity of the solvent }\end{array}$ & $\begin{array}{l}\text { Particle size and MWCO } \\
\text { of the utilized filter } \\
\text { membrane }\end{array}$ \\
\hline Recovery & । & $\mathrm{H}$ \\
\hline Purity & $\mathrm{H}$ & L \\
\hline Specificity & I & L \\
\hline Sample volume & । & $\mathrm{H}$ \\
\hline Efficiency & । & । \\
\hline Time & $\mathrm{H}$ & $\mathrm{H}$ \\
\hline Cost & L & । \\
\hline Complexity & । & L \\
\hline Functionality of exosomes & । & । \\
\hline Scalability & I & $\mathrm{H}$ \\
\hline Advanced equipment & । & L \\
\hline References & {$[113-117]$} & [118-121] \\
\hline
\end{tabular}

$L$ low, I intermediate, $H$ high

Recovery: exosomal yield; purity: the ability of isolating exosomes with minimum contamination; specificity: the ability to separate exosomes from nonexosomal content; sample volume: the required amount of starting material; efficiency: sample processing with high quality; time: the ability to isolate exosomes in a short amount of time; cost: the required amount of money; complexity: the need for training before use; functionality of exosomes: the use of isolated exosomes for downstream functional analysis without changing their efficacy; scalability: the ability to isolate exosomes from large sample volumes without overly increasing time, cost, or personnel required; advanced equipment: the need for expensive equipment and device

which possesses a lower density than that of any of the sample particles [41]. Then the intended centrifugal force is exercised and the sample components start to travel through the gradient density, which gradually grows from the top to the bottom of the tube, and the particles are finally separated into various zones of the tube. Since the sample particles are denser than the gradient medium, RZUC separates components primarily based on their size and shape rather than by density [44]. The larger components and also the more spherically symmetrical particles migrate more rapidly through the gradient [44]. The duration of the centrifugation phase is of significant importance, and if not properly optimized, all particles will finally copellet at the bottom of the tube since they are all denser than the gradient [28]. To avoid exosome sedimentation, a high-density cushion is typically applied to layer the bottom of the centrifuge tube [41]. The capacity of RZUC is limited due to small loading region of the centrifuge tube which presents an obstacle for large-scale exosome preparations of clinical relevance [44].

Isopycnic ultracentrifugation: Isopycnic ultracentrifugation (IPUC) (also known as buoyant DUC or equilibrium DGUC) recruits the concept of buoyancy for separating particles based on their density. The sample density should be between the lowest and highest density range of the gradient [45]. In IPUC, the sample is located in a dense medium at the bottom of the gradient or uniformly mixed with a self-generating gradient substance such as $\mathrm{CsCl}$ [41]. Following a long high-speed centrifugation, a steep density gradient is created in the centrifuge tube [46]. As components distribute, they form bands (so-called the isopycnic position) where the buoyant density of the collected particles matches with the gradient density of the surrounding solution. The separation of exosomes into a distinct region merely depends on their density difference from all other components if a sufficient time of centrifugation is applied [41]. The banded exosomes are retrieved from the density zone between 1.10 and $1.21 \mathrm{~g} / \mathrm{mL}$ by fractionation, which is performed either by removing certain amounts of fractions from the top of the tube or by draining particles with a long-needle syringe. The concentrated exosome aliquot is then subjected to a short $\mathrm{UC}$ at $\sim 100,000 \mathrm{~g}$ and resuspended in PBS for further analysis [41]. IPUC is a very precise technique with the ability of differentiating exosomes from other vesicles like apoptotic bodies and microvesicles as well as soluble proteins [28]. However, it is not generally applicable to clinical-scale exosome preparations [46].

\section{Ultrafiltration}

As is the case with any other conventional membrane filtration, ultrafiltration (UF) separates exosomes on the basis of their size and molecular weight cut-off (MWCO) of the utilized membrane filter. MWCO is an arbitrary unit representative of membrane pore size, which is utilized for characterizing UF membranes. UF membranes were initially used to purify biological fluids for retaining 
macromolecules particularly peptides and globular proteins. Since biological macromolecules are described by their molecular weight, the ability of UF membranes to retain these macromolecules is defined by their molecular weight. MWCO is described as the molecular weight where $90 \%$ of the macromolecular component is rejected by the membrane. Exosomes larger than pores of the membrane are held by it and smaller components are transited through the membrane. One major drawback of UF is the trapping and clogging of exosomes on membrane filter. Thus, they cannot be recovered for downstream analysis [39]. However, the isolation efficiency can be improved by starting the process with large MWCO membranes and then shifting to smaller ones [39]. UF is simpler and faster than UC, does not involve any special equipment, and can be easily scaled up and applied to the clinical field of exosomes [36, 47]. However, UF may sometimes result in exosomal damage because of the implemented shear force, which can be minimized through careful regulation of the pressure exerted on the membrane [33].

Sequential filtration (SF) is a UF technique used for isolation of exosomes by successive steps of filtration. First, the biosample is loaded on a 100-nm filter, which sieves out cells and large rigid cellular components and debris by dead-end (normal) filtration. Although their diameter is larger than $100 \mathrm{~nm}$, different $\mathrm{EV}$ populations pass through this filter since they are flexible and soft [48]. The remaining contaminants like soluble proteins are then eliminated by tangential flow filtration using a $500-\mathrm{kDa}$ MWCO membrane and the biosample is further concentrated. The filtrate is once more passed through a membrane filter, so-called track-etch membrane, with defined pore sizes $(100 \mathrm{~nm})$ at very low pressure in order to inhibit passing of flexible nonexosomal EVs into the filtrate while allowing for passage of exosomes. SF is one of the most efficient methods which is performed within a day. The process is automation-friendly and due to low manipulation forces, results in intact high-purity functional exosomes. Additionally, SF is capable of isolating exosomes from large sample volumes (up to $1 \mathrm{~L}$ ) [34], which has been implemented in clinical trials [49].

\section{Application of mesenchymal stem cell-derived exosomes in regenerative medicine}

The therapeutic effects of MSC exosomes in preclinical studies are depicted in Fig. 2 and the details are summarized in Table 2.

\section{Cardiovascular diseases}

The cardioprotective effects of exosomes secreted from MSCs was investigated in a rat myocardial infarction (MI) model using vesicles from human bone marrow-derived
MSCs (hBM-MSCs). Intramyocardial injection of exosomes was reported to improve cardiac indices such as cardiac systolic and diastolic performances and blood flow [50]. MSC exosomes were also able to exert therapeutic effects by reducing vascular remodeling and hypoxic pulmonary hypertension in mice. These outcomes were mediated by inactivation of signal transducer and activator of transcription 3 (STAT3) pathway and upregulation of miR-204 in the lung cells [51]. Exosomes released from genetically modified rat BM-MSCs overexpressing CXCR4 (Exo ${ }^{\mathrm{CR} 4}$ ) were reported to enhance the levels of insulin-like growth factor $1 \alpha$ (IGF1 $\alpha)$ and pAkt, inhibit caspase 3, and promote vascular endothelial growth factor (VEGF) upregulation and tubulogenesis in cultured cardiomyocytes. Moreover, when Exo ${ }^{\mathrm{CR} 4}$-pretreated MSCsheet was engrafted into the damaged myocardium of a rat MI model, the infarct size remarkably decreased and angiogenesis was triggered [52]. In another study, BMMSC exosomes promoted tube formation by endothelial cells as well as $\mathrm{T}$ cell inhibition, reduction of the infarct size, and recovery of cardiac systolic and diastolic performances $[53,54]$. Investigation of the role of exosomal miRNA molecules demonstrated that miR-22-enriched exosomes were notably successful in decreasing the infarct size and cardiac fibrosis in a murine post-MI model via targeting MECP2 (methyl-CpG-binding protein 2) [55]. BM-MSC exosomes carrying miR-221 exhibited anti-apoptotic and cardioprotective effects by downregulating PUMA (p53 upregulated modulator of apoptosis) expression in vitro [56]. Another work performed by the same team revealed that exosomal miR-19a could reduce the infarct size and restore cardiac function through downregulating phosphatase and tensin homolog (PTEN) and triggering the Akt and ERK signaling pathways in an acute MI rat model [57]. Additionally, exosomal miR-210 were shown to promote angiogenesis and retain cardiac function both ex vivo and in vivo [58]. In an attempt to explore the cardioprotective effects of endometriumderived MSC exosomes, exosome-mediated shuttling of miR-21 was attributed to the suppression of PTEN, stimulation of Akt, and upregulation of $\mathrm{Bcl}-2$ and VEGF. As a result, cardiac function was restored and the infarct size was diminished [59]. Notable results were also found by Zhang et al. when cardiac stem cells were preconditioned with BM-MSC exosomes and administered to a rat model of MI [60]. Here, cardiac fibrosis was reduced and survival and capillary density were drastically improved.

\section{Kidney diseases}

In order to investigate the renoprotective effects of BM-MSC exosomes, Bruno et al. found that exosomal mRNAs encoding CDC6, CDK8 and CCNB1 along with exosomal hepatocyte growth factor (HGF) and IGF1 


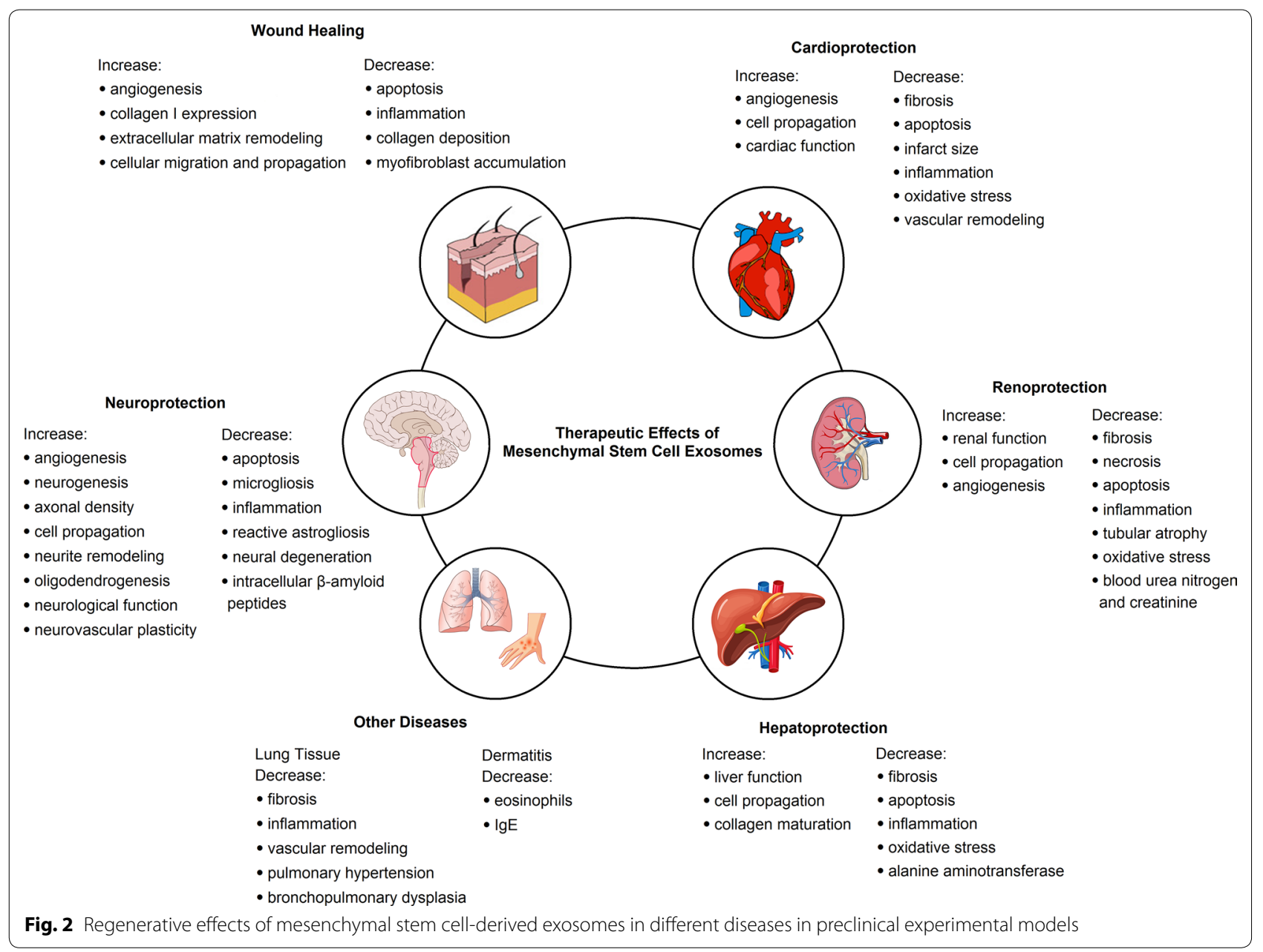

mediated cell cycle entry and subsequent proliferation of tubular epithelial cells while blocking apoptosis [61]. The renoprotective effects of AD-MSC exosomes overexpressing glial cell line-derived neurotrophic factor (GDNF) was investigated on renal injury using a ureteral obstruction murine model. Here, exosomes could decrease peritubular capillary rarefaction and renal fibrosis. Moreover, they stimulated angiogenesis, cell migration, sirtuin 1 signaling pathway as well as conferring apoptosis resistance [62]. In a rat model of ischemia-reperfusion injury (IRI), BM-MSC exosome administration was associated with improved tubular epithelial cell proliferation and survival [63], most probably via exosomal miRNA and mRNA molecules mediating renoprotective signaling pathways [64]. Exosomes released form kidneyderived MSCs were also recently reported to induce angiogenesis in the renal tissue by harboring pro-angiogenic mRNA molecules encoding basic fibroblast growth factor (bFGF), IGF1 and VEGF [65]. In another study on a rat model of renal IRI, adipocyte-derived MSC (AD-MSC) exosomes reduced the levels of creatinine and blood urea nitrogen (BUN) and improved renal function via downregulating pro-inflammatory cytokines and Smad3 and TGF $\beta$ fibrotic proteins as well as enhancing anti-apoptotic proteins and angiogenic biomarkers [66]. In a gentamycin-induced AKI model, administration of BM-MSC exosomes remarkably reduced inflammation by upregulating IL10 and downregulating TNF $\alpha$ and IL6 expression [67]. In an attempt to explore the antioxidant effects of MSC exosomes in the kidney tissue, it was revealed that exosomes derived from human Wharton's jelly MSCs (hWJ-MSCs) could repress NADPH oxidase (NOX) and reactive oxygen species [68] while triggering Nrf2/antioxidant response element [69], which led to improved renal function and apoptosis inhibition. In a cisplatin-induced AKI model, hWJ-MSC exosomes were reported to stimulate autophagy by upregulating autophagy-related genes such as ATG5, ATG-7, and LC3B [70]. Exosomes released by hWJ-MSCs were also reported to successfully decrease BUN and creatinine levels, necrosis of proximal kidney tubules, and production of tubular protein casts through anti-oxidative and anti-apoptosis pathways [71]. Further 


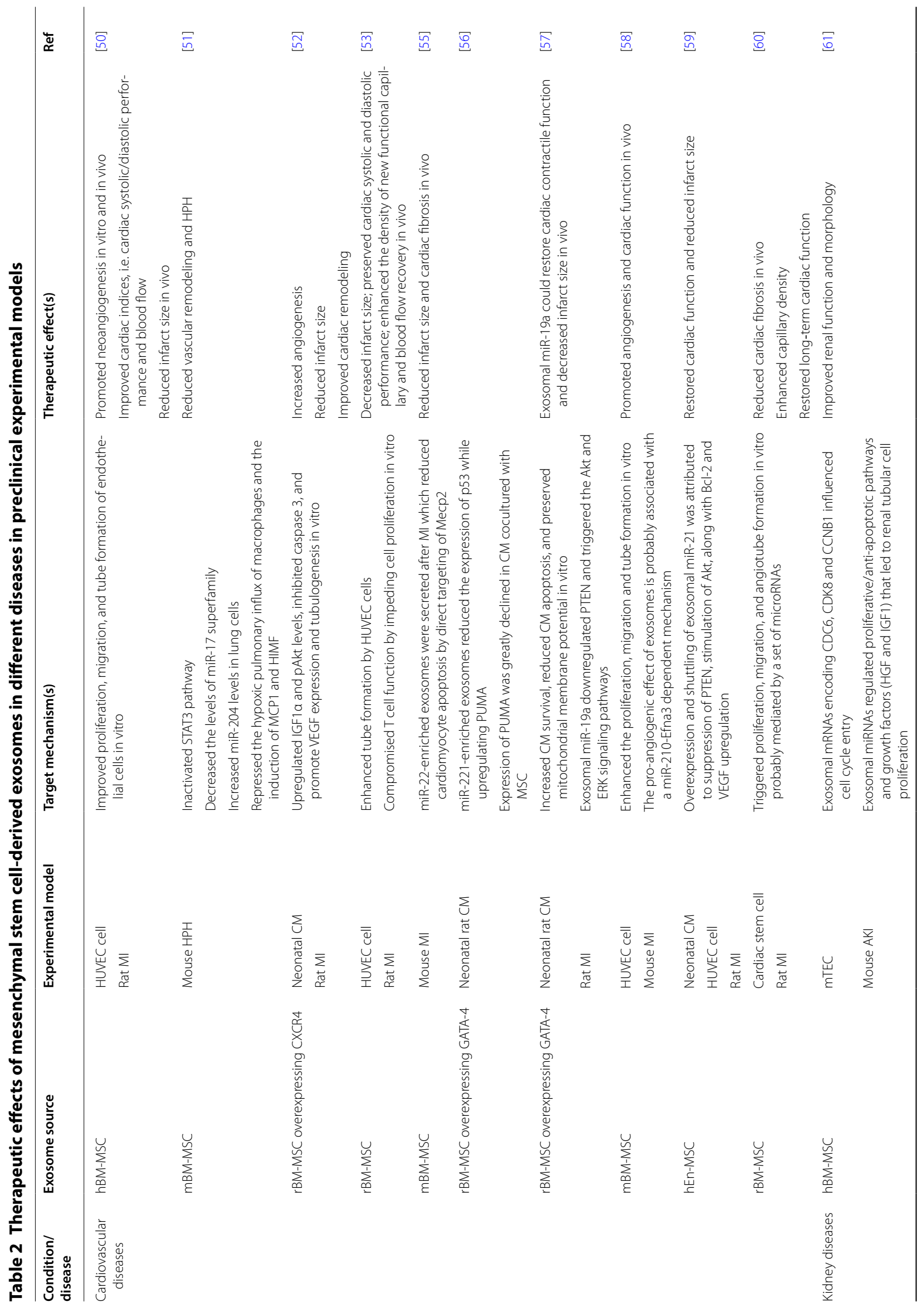




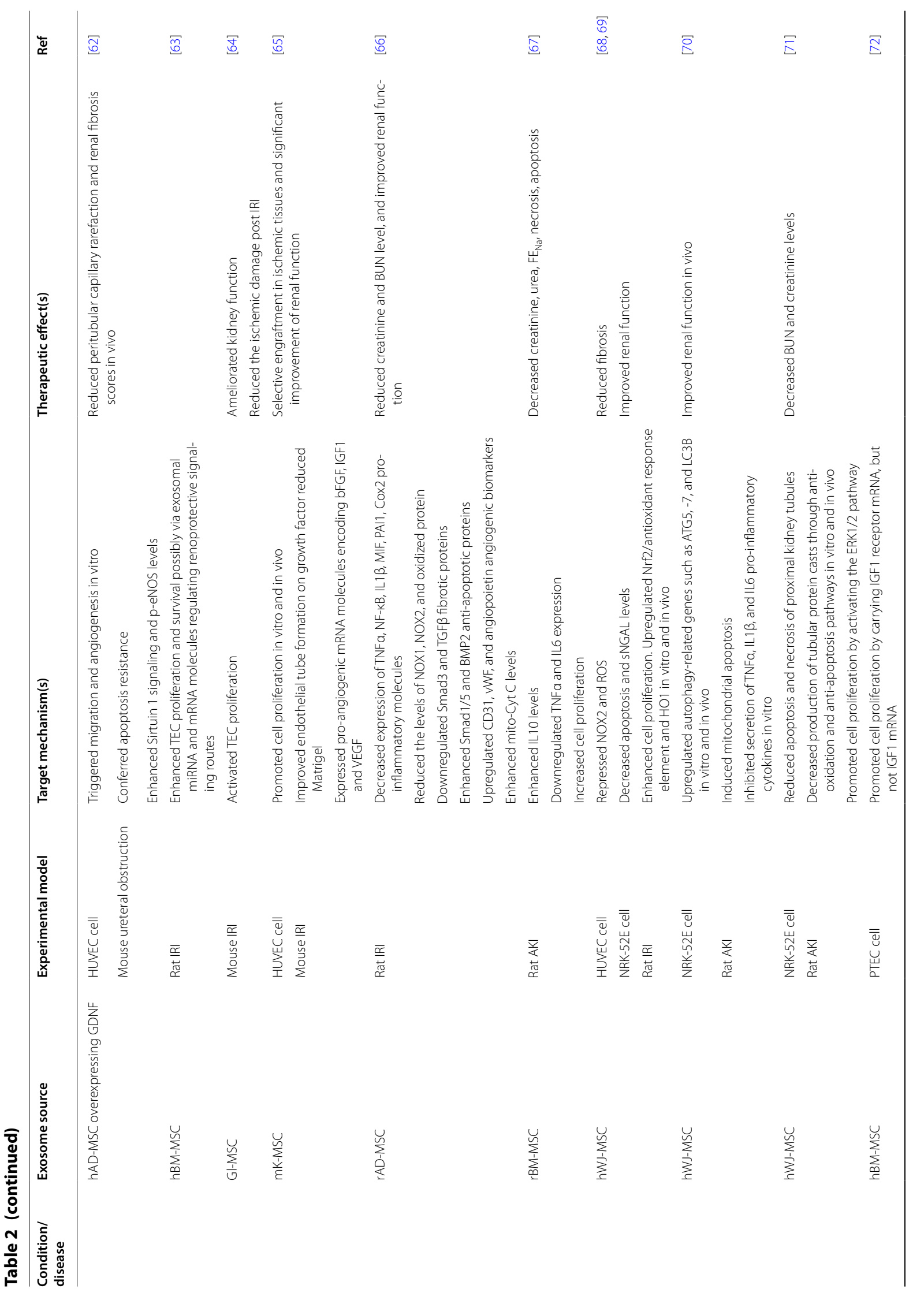




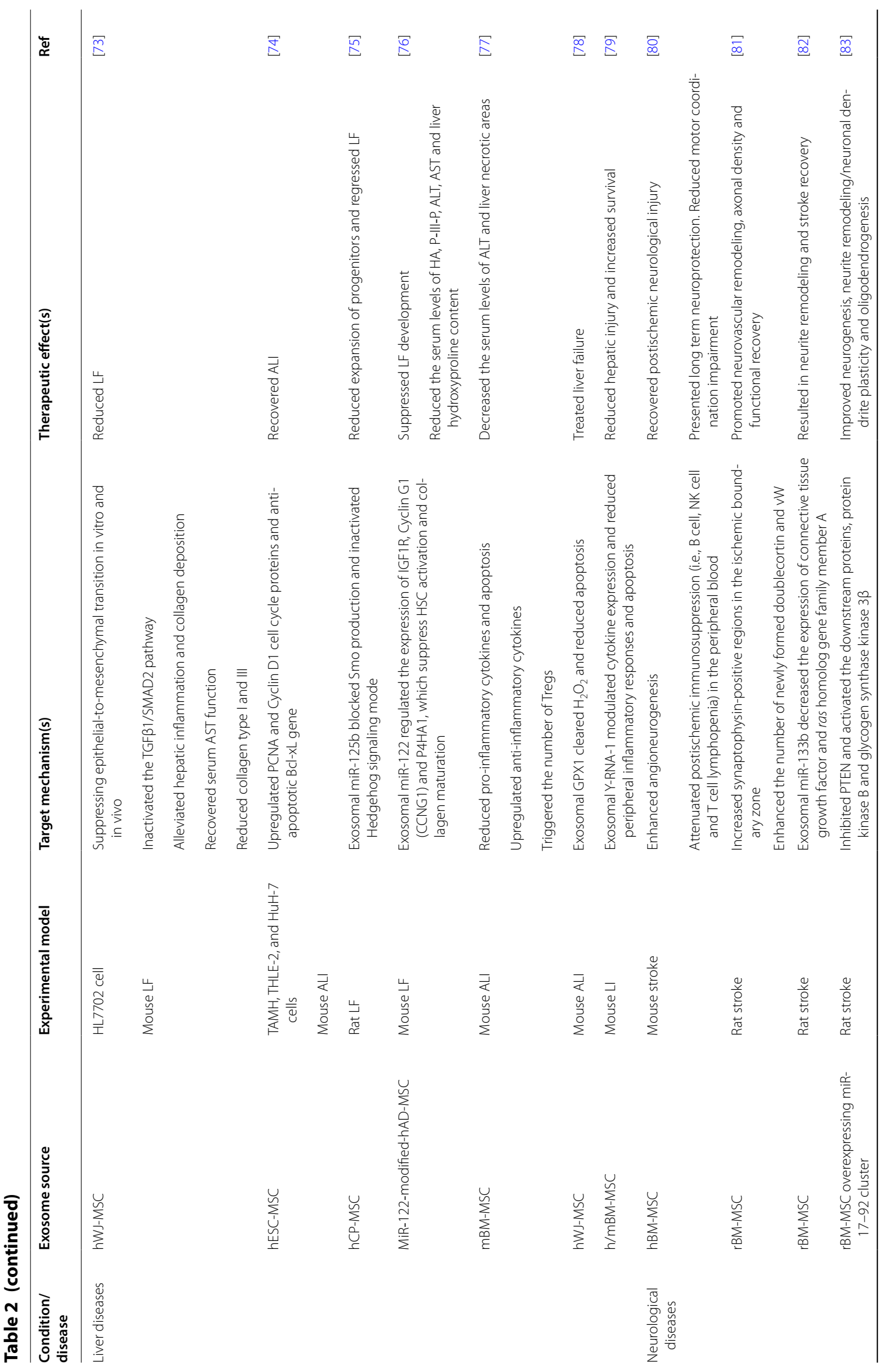


Nikfarjam et al. J Transl Med $\quad$ (2020) 18:449

Page 11 of 21
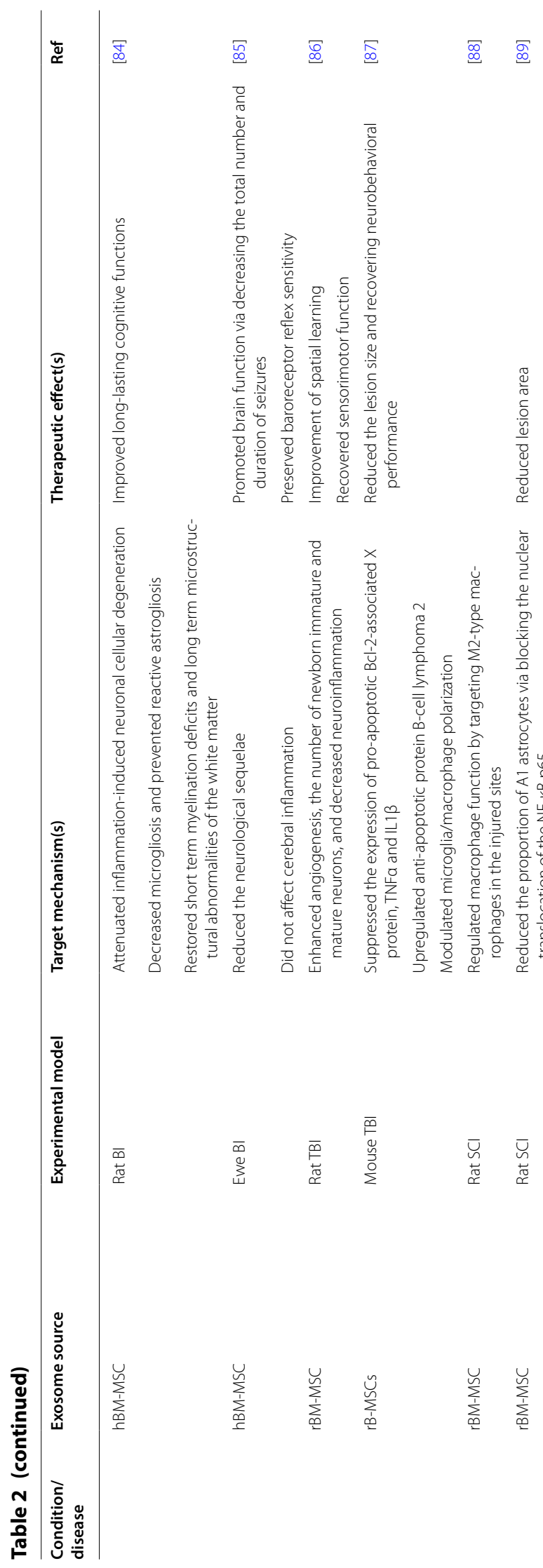

ஓ

$\check{\sigma}$

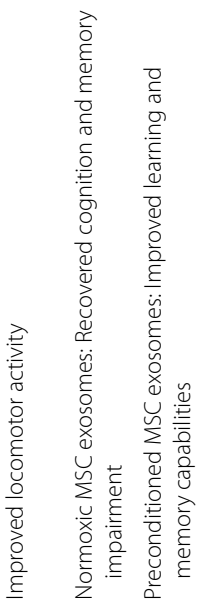

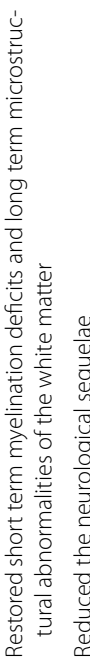

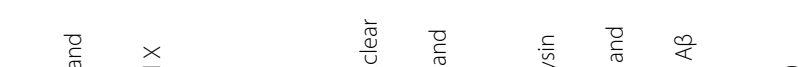

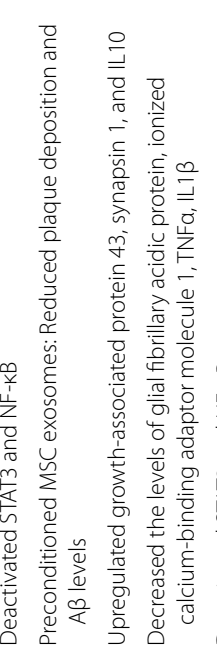

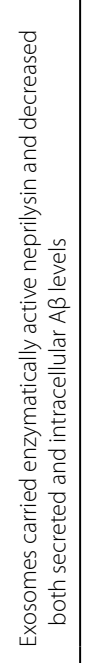


Nikfarjam et al. J Transl Med ～(2020) 18:449

Page 12 of 21

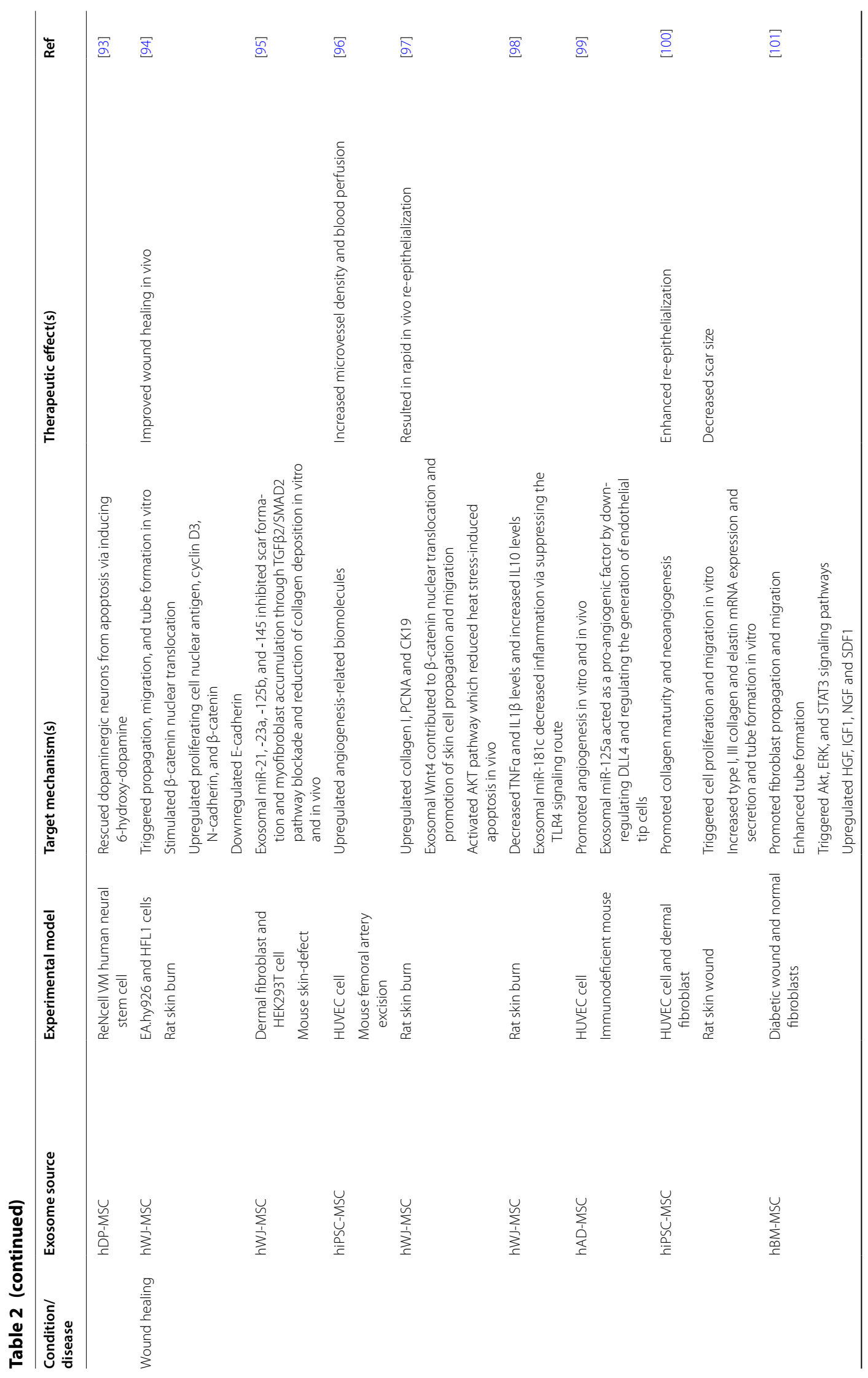




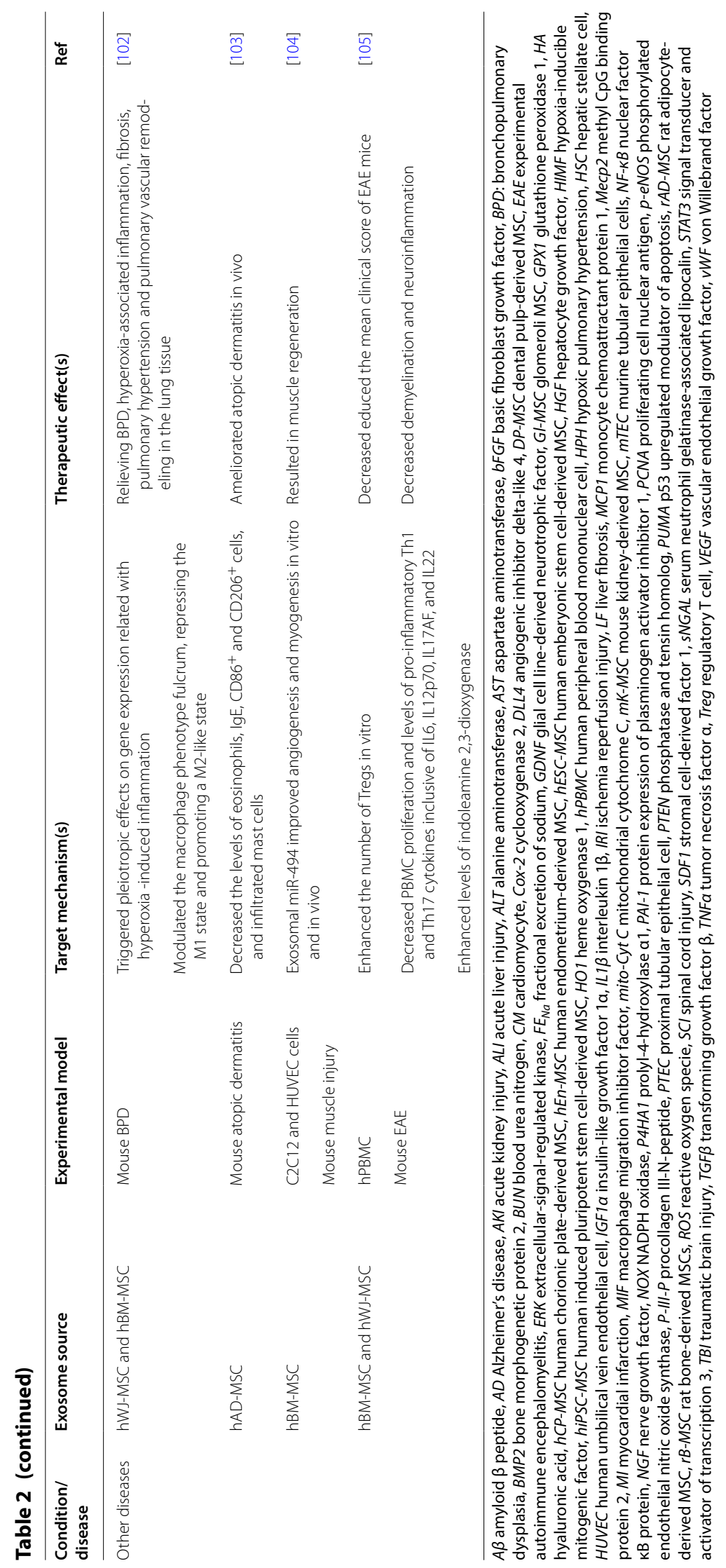


studies have shown that when BM-MSC exosomes were co-incubated with cisplatin-injured proximal tubular epithelial cells, they were capable of promoting cell proliferation by conveying IGF1 receptor mRNA [72].

\section{Liver diseases}

Exosomes secreted by MSCs were also utilized in numerous studies for exploring their therapeutic effects in liver diseases. Transplantation of hWJ-MSC exosomes in a carbon tetrachloride $\left(\mathrm{CCl}_{4}\right)$-induced liver injury (LI) murine model was shown to limit liver fibrosis (LF) and protect hepatocytes by suppressing epithelial-tomesenchymal transition and inactivating the transforming growth factor $\beta 1$ (TGF $\beta 1$ )/SMAD2 pathway [73]. Hepatoprotective effects of exosomes isolated from human embryonic stem cell-derived MSCs (hESC-MSCs) were explored in an in vitro model of acetaminophen/ $\mathrm{H}_{2} \mathrm{O}_{2}$-induced LI and a murine model of $\mathrm{CCl}_{4}$-induced acute LI, and it was revealed that these exosomes contributed to tissue regeneration through upregulating the expression of PCNA and Cyclin D1 cell cycle regulators and anti-apoptotic Bcl-xL gene [74]. In a separate study using a mouse model of $\mathrm{CCl}_{4}$-induced LF, it was revealed that exosomes released by chorionic plate-derived MSCs harbored miR-125b that demonstrated hepatoprotective effect by blocking Smo production and thus inactivating Hedgehog signaling route [75]. Furthermore, it was revealed that AD-MSC exosomes shuttle miR-122 to hepatic stellate cells (HSCs) and regulate the expression of miR-122 target genes including IGF1R, Cyclin G1 (CCNG1) and prolyl-4-hydroxylase $\alpha 1$ (P4HA1), which affect cell proliferation and collagen maturation in HSCs [76]. The application of BM-MSC exosomes in a concanavalin A-induced LI (a case of immune-induced LI) could decrease the serum levels of alanine aminotransferase (ALT) and pro-inflammatory cytokines while enhancing the expression of anti-inflammatory cytokines and regulatory $\mathrm{T}$ cell (Treg) activity [77]. In another work, a single administration of hWJ-MSC exosomes harboring glutathione peroxidase 1 (GPX1), a vital human anti-oxidant, in a murine acute LI model could treat the disease via clearing hydrogen peroxide and relieving oxidative stress and cell death [78]. Exosomal Y-RNA-1 molecules were demonstrated to recover LI and increase survival by adjusting peripheral inflammatory responses and triggering anti-apoptosis effects in a lethal murine model of $\mathrm{D}$-galactosamine/TNF $\alpha$-induced liver failure [79].

\section{Neurological diseases}

Exosomes released from BM-MSCs were reported to exhibit therapeutic effects as they recover post-ischemic neurological injuries, enhance angioneurogenesis, and represent long-term neuroprotective functions in a murine stroke model [80]. When BM-MSC exosomes were administered intravenously to a rat stroke model, neurovascular plasticity was promoted and axonal density and synaptophysin-positive regions were improved in the ischemic margin zone of striatum and cortex [81]. Further investigations regarding BM-MSC exosomes showed that they contain miR-133b, which contributes to neurite remodeling and consequent stroke recovery upon delivery to astrocytes and neurons [82]. Additionally, it was revealed that these exosomes carry the miR-17-92 cluster, which mediates neurogenesis, neural remodeling and oligodendrogenesis in the ischemic boundary region [83]. Here, it was further demonstrated that miR-17-92 cluster-enriched exosomes have the potential of inhibiting PTEN (a confirmed target gene of miR-1792 cluster) and consequently activating the downstream proteins, protein kinase $B$ (mechanistic target of rapamycin) and glycogen synthase kinase $3 \beta$. In a laboratory model of inflammation-induced preterm brain injury, BM-MSC exosomes were reported to impede neural degeneration, microgliosis and inhibit reactive astrogliosis [84]. In another study, a reduction of the neurological sequelae and recovery of brain function was shown upon injection of BM-MSC exosomes [85]. While exploring the neuroprotective effects of BM-MSC exosomes in traumatic brain injury (TBI), researchers found that exosomes resulted in the promotion of angiogenesis and neuronal growth rate along with reduction of inflammation in lesion boundary zone and dentate gyrus after TBI [86]. In a separate TBI study, exosomes isolated from bone-derived MSCs (B-MSCs) exhibited neuroprotective effects by reducing the lesion size and recovering neurobehavioral performance. These outcomes were mediated by suppressing the expression of pro-apoptotic $\mathrm{Bcl}-2$-associated X protein, TNF $\alpha$ and IL1 $\beta$, upregulation of anti-apoptotic protein B-cell lymphoma 2 , and modulating microglia/macrophage polarization [87]. In spinal cord injuries (SCIs), intravenously-delivered exosomes were shown to regulate macrophage functions by targeting M2-type macrophages in the injured sites [88]. Intravenous injection of BM-MSC exosomes was also reported to diminish the proportion of SCI-induced A1 astrocytes, the percentage of $\mathrm{p} 65$ positive nuclei in astrocytes, and the expression of IL1 $\alpha$, IL1 $\beta$ and TNF $\alpha$. These mechanisms were ascribed to nuclear translocation of the NF-kB p65 [89]. Similar results were reported when systemic administration of BM-MSC exosomes showed anti-inflammatory responses in the damaged cord tissue and improved locomotor activity via disorganization of astrocytes and microglia [90]. Exosomes isolated from hypoxia-preconditioned BM-MSCs could rescue synaptic dysfunction and promote anti-inflammatory effects in an APP/PS1 murine model of Alzheimer's disease (AD) [91]. 
In another study of $\mathrm{AD}$, it was shown that $\mathrm{AD}$-MSCs secrete exosomes containing an abundance of neprilysin, the most utilized enzyme for degradation of $\beta$-amyloid peptides in the brain tissue. The levels of secreted and intracellular $\beta$-amyloid peptides were decreased when these exosomes were transferred into neuroblastoma cells [92]. In a separate study, exosomes released from dental pulp MSCs (DP-MSCs) were reported to rescue dopaminergic neurons from apoptosis via inducing 6-hydroxy-dopamine in a 3D culture [93].

\section{Wound healing}

Exosomes secreted from hWJ-MSCs contribute to wound healing process via transferring Wnt 4 and activating $\beta$-catenin, which leads to angiogenesis in vivo [94]. Exosomal miRNAs including miR-21, -23a, -125b, and -145 from hWJ-MSCs were reported to impede scar formation and myofibroblast accumulation through TGF $32 / S M A D 2$ pathway blockade and reduction of collagen deposition [95]. MSC exosomes were also able to trigger the expression of angiogenesis-related biomolecules and increase microvessel density and blood perfusion in the ischemic limbs of a murine model [96]. Wounds treated with hWJ-MSC exosomes demonstrated rapid in vivo re-epithelialization as well as upregulating the expression of collagen I, PCNA and CK19. Furthermore, these exosomes harbored Wnt 4 that contributed to $\beta$-catenin nuclear translocation and promotion of skin cell propagation and migration [97]. MSC exosomes were also reported to ameliorate burn-induced inflammation in cutaneous wound healing. For example, hWJMSC exosomes exhibited anti-inflammatory effects via reducing mRNA levels of pro-inflammatory cytokines such as IL1 $\beta$ and TNF $\alpha$ while increasing IL10 levels [98]. In another study, it was shown that AD-MSC exosomes were enriched in miR-125a that acted as a pro-angiogenic factor by downregulating the angiogenic inhibitor delta-like 4 (DLL4) expression and modulating the generation of endothelial tip cells [99]. Transplantation of exosomes derived from human induced pluripotent stem cell-derived mesenchymal stem cells (hiPSC-MSCs) to the wound sites in a rat model led to rapid re-epithelialization, promoted collagen maturity, and decreased the scar size. Additionally, these vesicles triggered cell proliferation and migration and increased the secretion of type I, III collagen and elastin in a dose-dependent manner in vitro [100]. Exosomal miR-181c contributed to the suppression of TLR4 signaling route. Here, exosomes derived from BM-MSCs could dose-dependently promote fibroblast propagation and migration, tube formation, trigger Akt, ERK, and STAT3 signaling pathways, and upregulate HGF, IGF1, nerve growth factor (NGF) and stromal cell-derived factor 1 (SDF1) expression [101].

\section{Other diseases}

In the lung, exosomes isolated from WJ-MSCs demonstrated remarkable therapeutic effects by relieving bronchopulmonary dysplasia, hyperoxia-associated inflammation, fibrosis, pulmonary hypertension and pulmonary vascular remodeling through adjusting the phenotype of lung macrophages [102]. In a murine atopic dermatitis model, AD-MSC exosomes could decrease the levels of eosinophils, IgE, CD86 ${ }^{+}$and $\mathrm{CD} 206^{+}$cells, and the infiltrated mast cells [103]. Exosomal miR-494 contributed to muscle regeneration via improving angiogenesis and myogenesis [104]. Study of BM-MSC exosomes in an experimental autoimmune encephalomyelitis model of multiple sclerosis revealed that they were capable of downregulating pro-inflammatory cytokines and inducing Tregs [105].

\section{Mesenchymal stem cell-derived exosomes in clinical trials}

Preclinical data have proven the safety of exosome therapy and scalability of their isolation methods from MSCs for clinical application. However, the use of MSC exosomes in clinical setting is limited due to the lack of established cell culture conditions and optimal protocols for production, isolation and storage of exosomes, optimal therapeutic dose and administration schedule, and reliable potency assays to evaluate the efficacy of exosome therapy [106-108]. There are numerous studies investigating the efficiency of MSC exosomes in the clinical settings. Although most of the clinical trials are in the recruitment and active phases, some of them have completed without publishing their results. Kordelas et al. tested the therapeutic effects of BM-MSCs in patients with steroid refractory graft-versus-host disease and found that the secretion of IL1 $\beta$, TNF $\alpha$, and IFNY by PBMCs were remarkably reduced following the third exosome application [109]. In line with the ameliorated pro-inflammatory response of the PBMCs, the disease symptoms improved significantly shortly after the MSC exosome therapy started. In another study, Nassar et al. showed that the application of UC-MSC exosomes led to overall improvement in renal function in patients suffering from grade III-IV chronic kidney disease [110]. Here, exosome therapy resulted in remarkable improvement of plasma creatinine level, estimated glomerular filtration rate, blood urea and urinary albumin creatinine ratio. Furthermore, serum levels of IL10 and TGF $\beta 1$ were increased while serum levels of TNF $\alpha$ were decreased. There are also other ongoing trials performed to determine the safety and effectiveness of human MSC exosomes in treatment of tissue injuries which are summarized in Table 3. 
Table 3 Mesenchymal stem cell-derived exosomes in clinical trials (https://www.clinicaltrials.gov/)

\begin{tabular}{|c|c|c|c|c|c|c|c|}
\hline Organ & Condition/disease & Trial ID/Ref & Phase & Status & $\begin{array}{l}\text { Source } \\
\text { of exosomes }\end{array}$ & Dose/frequency/route & Location \\
\hline \multirow[t]{17}{*}{ Lung } & \multirow[t]{7}{*}{ Healthy } & \multirow[t]{7}{*}{ NCT04313647 } & \multirow[t]{7}{*}{ । } & \multirow[t]{7}{*}{ Recruiting } & \multirow[t]{7}{*}{ AD-MSC } & $1 \times$ level: $2.0 \times 10^{8} / 3 \mathrm{ml}$ & \multirow[t]{7}{*}{ China } \\
\hline & & & & & & $2 \times$ level: $4.0 \times 10^{8} / 3 \mathrm{ml}$ & \\
\hline & & & & & & $4 \times$ level: $8.0 \times 10^{8} / 3 \mathrm{ml}$ & \\
\hline & & & & & & $6 \times$ level: $12.0 \times 10^{8} / 3 \mathrm{ml}$ & \\
\hline & & & & & & $8 \times$ level: $16.0 \times 10^{8} / 3 \mathrm{ml}$ & \\
\hline & & & & & & $10 \times$ level: $20.0 \times 10^{8} / 3 \mathrm{ml}$ & \\
\hline & & & & & & $\begin{array}{l}\text { All experiments: once; } \\
\text { aerosol inhalation }\end{array}$ & \\
\hline & \multirow{6}{*}{$\begin{array}{l}\text { SARS-CoV-2 pneu- } \\
\text { monia }\end{array}$} & \multirow[t]{3}{*}{ NCT04276987 } & \multirow[t]{3}{*}{ । } & \multirow[t]{3}{*}{ Completed } & \multirow[t]{3}{*}{ AD-MSC } & $2.0 \times 10^{8} / 3 \mathrm{ml}$ & \multirow[t]{3}{*}{ China } \\
\hline & & & & & & Once a day during 5 days & \\
\hline & & & & & & Aerosol inhalation & \\
\hline & & \multirow[t]{3}{*}{ NCT04491240 } & \multirow[t]{3}{*}{ ।, II } & \multirow[t]{3}{*}{ Enrolling by invitation } & \multirow[t]{3}{*}{ MSC } & $\begin{array}{l}\text { Procedure 1: } \\
\quad 0.5-2 \times 10^{10} / 3 \mathrm{ml}\end{array}$ & \multirow[t]{7}{*}{ Russia } \\
\hline & & & & & & $\begin{array}{l}\text { Procedure 2: } \\
\quad 0.5-2 \times 10^{10} / 3 \mathrm{ml}\end{array}$ & \\
\hline & & & & & & $\begin{array}{l}\text { All experiments: twice a day } \\
\text { during } 10 \text { days; inhalation }\end{array}$ & \\
\hline & \multirow{4}{*}{$\begin{array}{l}\text { Bronchopulmonary } \\
\text { dysplasia }\end{array}$} & \multirow[t]{4}{*}{ NCT03857841 } & \multirow[t]{4}{*}{ । } & \multirow[t]{4}{*}{ Recruiting } & \multirow[t]{4}{*}{ BM-MSC } & 20 pmol phospholid/kg & \\
\hline & & & & & & 60 pmol phospholid/kg & \\
\hline & & & & & & 200 pmol phospholid/kg & \\
\hline & & & & & & $\begin{array}{l}\text { All experiments: intravenous } \\
\text { injection }\end{array}$ & \\
\hline \multirow[t]{6}{*}{ Skin } & \multirow{3}{*}{$\begin{array}{l}\text { Dystrophic epider- } \\
\text { molysis bullosa }\end{array}$} & \multirow[t]{3}{*}{ NCT04173650 } & \multirow[t]{3}{*}{ I, II } & Not yet recruiting & BM-MSC & AGLE-102 exosomes & USA \\
\hline & & & & & & Once a day during 60 days & \\
\hline & & & & & & $\begin{array}{l}\text { Applied topically to the } \\
\text { entire body }\end{array}$ & \\
\hline & Chronic ulcer & NCT04134676 & । & Completed & WJ-MSC & Conditioned medium gel & Indonesia \\
\hline & & & & & & Every week for 2 weeks & \\
\hline & & & & & & $\begin{array}{l}\text { Applied topically to the } \\
\text { wound }\end{array}$ & \\
\hline Brain & Acute ischemic stroke & NCT03384433 & I, II & Completed & BM-MSC & $\begin{array}{l}200 \mu \mathrm{g} \text { total protein of miR- } \\
124 \text {-loaded exosomes }\end{array}$ & Iran \\
\hline & & & & & & One month after attack & \\
\hline & & & & & & Stereotactic guidance & \\
\hline & Alzheimer's disease & NCT04388982 & I, II & Not yet recruiting & AD-MSC & $\begin{array}{l}\text { Low dosage group: } 5 \text { Hg } \\
\text { exosome } / 1 \mathrm{ml}\end{array}$ & China \\
\hline & & & & & & $\begin{array}{l}\text { Mild dosage group: } 10 \mu \mathrm{gg} \\
\text { exosome } / 1 \mathrm{ml}\end{array}$ & \\
\hline & & & & & & $\begin{array}{l}\text { High dosage group: } 20 \mu \mathrm{g} \\
\text { exosome/1 ml }\end{array}$ & \\
\hline & & & & & & $\begin{array}{l}\text { All experiments: twice a } \\
\text { week during } 12 \text { weeks; } \\
\text { nasal drip }\end{array}$ & \\
\hline Eye & Macular holes & NCT03437759 & Early phase I & Recruiting & UC-MSC & $20-50 \mu \mathrm{g}$ exosome $/ 10 \mu \mathrm{l}$ & China \\
\hline & & & & & & Single dose & \\
\hline & & & & & & $\begin{array}{l}\text { Directly injected around } \\
\text { macular hole area }\end{array}$ & \\
\hline & Dry eye & NCT04213248 & I, II & Recruiting & UC-MSC & $10 \mu \mathrm{g}$ exosome/drop & China \\
\hline & & & & & & 4 times a day during 14 days & \\
\hline & & & & & & Eye drops & \\
\hline
\end{tabular}


Table 3 (continued)

\begin{tabular}{|c|c|c|c|c|c|c|c|}
\hline Organ & Condition/disease & Trial ID/Ref & Phase & Status & $\begin{array}{l}\text { Source } \\
\text { of exosomes }\end{array}$ & Dose/frequency/route & Location \\
\hline \multirow[t]{8}{*}{$\begin{array}{l}\text { Other } \\
\text { organs/ } \\
\text { tissues }\end{array}$} & Multiple organ failure & NCT04356300 & Not applicable & Not yet recruiting & UC-MSC & $\begin{array}{l}150 \text { mg exosome } \\
\text { Once a day during } 14 \text { days } \\
\text { Intravenous injection }\end{array}$ & China \\
\hline & $\begin{array}{l}\text { Diabetes mellitus } \\
\text { type } 1\end{array}$ & NCT02138331 & $\|, \mid\|$ & Unknown & UC-MSC & $\begin{array}{l}\text { First dose: Intravenous injec- } \\
\text { tion of exosomes isolated } \\
\text { from the supernatant } \\
\text { produced from } 1.22- \\
1.51 \times 10^{6} \mathrm{MSCs} / \mathrm{kg} \\
\text { Second dose: } 7 \text { days after } \\
\text { the first dose; intravenous } \\
\text { injection of MVs isolated } \\
\text { from the supernatant } \\
\text { produced from the same } \\
\text { dose of MSCs utilized in } \\
\text { the first injection }\end{array}$ & Egypt \\
\hline & Osteoarthritis & NCT04223622 & l & Not yet recruiting & AD-MSC & $\begin{array}{l}\text { Osteochondral explants } \\
\text { from arthroplasty } \\
\text { patients treated with } \\
\text { AD-MSC secretome (either } \\
\text { complete conditioned } \\
\text { medium or EVs) }\end{array}$ & Italy \\
\hline & $\begin{array}{l}\text { Graft-versus-host } \\
\text { disease }\end{array}$ & [109] & - & Concluded & BM-MSC & $\begin{array}{l}\text { 1.3-3.5 × } 10^{10} \text { exosome/unit; } \\
\text { 0.5-1.6 mg/unit (The yield } \\
\text { of an EV fraction isolated } \\
\text { from supernatants of } \\
4 \times 10^{7} \mathrm{MSC} \text { was defined } \\
\text { as one unit.) } \\
\text { First dose: a tenth of a unit } \\
\text { Second dose: } 2 \text { days } \\
\text { after the first dose, unit } \\
\text { amounts were progres- } \\
\text { sively enhanced and } \\
\text { administered every } \\
2-3 \text { days until } 4 \text { doses }\end{array}$ & Germany \\
\hline & $\begin{array}{l}\text { Chronic kidney } \\
\text { disease }\end{array}$ & {$[110]$} & $\|, \mid\|$ & Concluded & UC-MSC & $\begin{array}{l}100 \mu \mathrm{g} \text { of total EV protein/ } \\
\mathrm{kg}\end{array}$ & Egypt \\
\hline & & & & & & 2 doses ( 1 week apart) & \\
\hline & & & & & & $\begin{array}{l}\text { First dose: intravenous } \\
\text { injection }\end{array}$ & \\
\hline & & & & & & $\begin{array}{l}\text { Second dose: infused into } \\
\text { the renal artery }\end{array}$ & \\
\hline
\end{tabular}

\section{Concluding remarks}

Exosomes secreted by MSCs are now being extensively exploited to develop novel regenerative strategies for numerous diseases since they convey most of the therapeutic properties of MSCs. Exosomes offer a possibility of cell-free therapy, which minimizes safety concerns regarding the administration of viable cells. In many cases, the regenerative effect of MSC exosomes has been ascribed to their anti-inflammatory function in the recipient cells. Exploiting these immunomodulatory effects allows for the use of MSC-derived exosomes to treat different inflammatory and autoimmune diseases. The function of exosomes can be readily adjusted via preconditioning of MSC culture, for instance by addition of chemical factors or cytokines, exerting hypoxic conditions, and introducing gene modifications such as the CRISPR/Cas9 technology [111]. However, details about the functional mechanisms of exosomes in MSCs 
and their target cells continue to be elucidated. Moreover, there are still a few unresolved concerns before bringing MSC-derived exosomes into the clinical setting. Standards and guidelines should be established for vesicle size, purity, expression of certain surface biomarkers (e.g. CD9, CD63, CD81), and acceptable contamination levels for identification and quality control of the isolated exosomes. It was confirmed that the physiological state of MSCs influence the therapeutic efficiency of isolated exosomes [108]. This issue can be partly resolved by MSC preconditioning or extracting exosomes from induced pluripotent stem cells or embryonic stem cells [112] in order to diminish the lot-to-lot variation regarding primary naive MSCs. In summary, findings from various research works imply that MSC-derived exosomes possess promising therapeutic capacity for treatment of a variety of diseases. Efforts directed toward determining standards on the therapy efficacy and safety issues will speed up clinical implementation of MSC-derived exosomes as regenerative agents.

\begin{abstract}
Abbreviations
AD: Alzheimer's disease; AD-MSC: Adipocyte-derived mesenchymal stem cell; AKI: Acute kidney injury; Alix: ALG2-interacting protein X; bFGF: Basic fibroblast growth factor; B-MSC: Bone-derived mesenchymal stem cell; CAM: Cell adhesion molecule; $\mathrm{CCl}_{4}$ : Carbon tetrachloride; CRISPR: Clustered regularly interspaced short palindromic repeats; DLL4: Delta-like 4 protein; DGUC: Density gradient ultracentrifugation; DP-MSC: Dental pulp-derived mesenchymal stem cell; DUC: Differential ultracentrifugation; EV: Extracellular vesicle; GPX1: Glutathione peroxidase 1; hBM-MSC: Human bone marrow-derived mesenchymal stem cell; hESC-MSC: Human embryonic stem cell-derived mesenchymal stem cell; HGF: Hepatocyte growth factor; HSC: Hepatic stellate cell; hUC-MSC: Human umbilical cord blood-derived mesenchymal stem cell; hWJMSC: Human Wharton's jelly (umbilical cord matrix)-derived mesenchymal stem cell; IgE: Immunoglobulin E; IGF1a: Insulin-like growth factor 1a; IL1ß: Interleukin $1 \beta$; ILV: Intraluminal vesicle; IPUC: Isopycnic ultracentrifugation; IRI: Ischemia-reperfusion injury; K-MSC: Kidney-derived mesenchymal stem cell; LF: Liver fibrosis; LI: Liver injury; MECP2: Methyl-CpG-binding protein 2; MHC: Major histocompatibility complex; MI: Myocardial infarction; MSC: Mesenchymal stem/stromal cell; MVB: Multivesicular body; MWCO: Molecular weight cut-off; NADPH: Nicotinamide adenine dinucleotide phosphate; NGF: Nerve growth factor; P4HA1: Prolyl-4-hydroxylase a1; PBS: Phosphate buffered saline; PTEN: Phosphatase and tensin homolog; PUMA: P53 upregulated modulator of apoptosis; RBC: Red blood cell; RZUC: Rate-zonal ultracentrifugation; SCl: Spinal cord injury; SDF1: Stromal cell-derived factor 1; SF: Sequential filtration; STAT3: Signal transducer and activator of transcription 3; TBI: Traumatic brain injury; TGF $\beta 1$ : Transforming growth factor $\beta 1$; TNFa: Tumor necrosis factor $a$; UF: Ultrafiltration; UC: Ultracentrifugation; VEGF: Vascular endothelial growth factor.
\end{abstract}

\section{Acknowledgements}

Not applicable.

\section{Authors' contributions}

Conception and manuscript design: RJ. Collection of data: SN, JR, NMJ and RJ. Manuscript writing: SN, JR, NMJ and RJ. Made important revisions and confirmed final revision: RJ. All authors reviewed the final version of the manuscript. All authors read and approved the final manuscript.

\section{Funding}

Not applicable.
Availability of data and materials

Not applicable.

Ethics approval and consent to participate

Not applicable.

\section{Consent for publication}

Not applicable.

\section{Competing interests}

The authors declare that they have no competing interests.

\section{Author details}

${ }^{1}$ Department of Medical Biotechnology, Faculty of Advanced Medical Sciences, Tabriz University of Medical Sciences, Tabriz, Iran. ${ }^{2}$ Solid Tumor Research Center, Cellular and Molecular Medicine Research Institute, Urmia University of Medical Sciences, Shafa St, Ershad Blvd, P.O. BoX: 1138, 57147 Urmia, Iran. ${ }^{3}$ Department of Pharmacology and Toxicology, Faculty of Pharmacy, Urmia University of Medical Sciences, Urmia, Iran.

Received: 12 August 2020 Accepted: 18 November 2020

Published online: 27 November 2020

\section{References}

1. Teixeira FG, Carvalho MM, Sousa N, Salgado AJ. Mesenchymal stem cells secretome: a new paradigm for central nervous system regeneration? Cell Mol Life Sci. 2013;70(20):3871-82.

2. Akbari A, Jabbari N, Sharifi R, Ahmadi M, Vahhabi A, Seyedzadeh SJ, et al. Free and hydrogel encapsulated exosome-based therapies in regenerative medicine. Life Sci. 2020;249:117447.

3. Lai RC, Yeo RW, Lim SK. Mesenchymal stem cell exosomes. Semin Cell Dev Biol. 2015;40:82-8.

4. Smirnov SV, Harbacheuski R, Lewis-Antes A, Zhu H, Rameshwar P, Kotenko SV. Bone-marrow-derived mesenchymal stem cells as a target for cytomegalovirus infection: implications for hematopoiesis, selfrenewal and differentiation potential. Virology. 2007;360(1):6-16.

5. Crapnell K, Blaesius R, Hastings A, Lennon DP, Caplan Al, Bruder SP. Growth, differentiation capacity, and function of mesenchymal stem cells expanded in serum-free medium developed via combinatorial screening. Exp Cell Res. 2013;319(10):1409-18.

6. Krause DS, Theise ND, Collector MI, Henegariu O, Hwang S, Gardner $\mathrm{R}$, et al. Multi-organ, multi-lineage engraftment by a single bone marrow-derived stem cell. Cell. 2001;105(3):369-77.

7. Wagers AJ, Weissman IL. Plasticity of adult stem cells. Cell. 2004;116(5):639-48.

8. Prockop DJ, Oh JY. Medical therapies with adult stem/progenitor cells (MSCs): a backward journey from dramatic results in vivo to the cellular and molecular explanations. J Cell Biochem. 2012;113(5):1460-9.

9. Theise ND. On experimental design and discourse in plasticity research. Stem Cell Rev. 2005;1(1):9-13.

10. Iso Y, Spees JL, Serrano C, Bakondi B, Pochampally R, Song YH, et al. Multipotent human stromal cells improve cardiac function after myocardial infarction in mice without long-term engraftment. Biochem Biophys Res Commun. 2007;354(3):700-6.

11. Rani $S$, Ryan AE, Griffin MD, Ritter T. Mesenchymal stem cell-derived extracellular vesicles: toward cell-free therapeutic applications. Mol Ther. 2015;23(5):812-23.

12. Rezaie J, Ajezi S, Avci ÇB, Karimipour M, Geranmayeh MH, Nourazarian A, et al. Exosomes and their application in biomedical field: difficulties and advantages. Mol Neurobiol. 2018;55(4):3372-93.

13. Pan BT, Johnstone RM. Fate of the transferrin receptor during maturation of sheep reticulocytes in vitro: selective externalization of the receptor. Cell. 1983;33(3):967-78.

14. Johnstone RM, Adam M, Hammond J, Orr L, Turbide C. Vesicle formation during reticulocyte maturation. Association of plasma membrane activities with released vesicles (exosomes). J Biol Chem. 1987;262(19):9412-20. 
15. Johnstone RM. Revisiting the road to the discovery of exosomes. Blood Cells Mol Dis. 2005;34(3):214-9.

16. Trams EG, Lauter CJ, Salem JN, Heine U. Exfoliation of membrane ecto-enzymes in the form of micro-vesicles. Biochimica et Biophysica Acta (BBA). 1981;645(1):63-70.

17. Potolicchio I, Carven GJ, Xu X, Stipp C, Riese RJ, Stern LJ, et al. Proteomic analysis of microglia-derived exosomes: metabolic role of the aminopeptidase CD13 in neuropeptide catabolism. J Immunol. 2005; 175(4):2237-43.

18. Février B, Raposo G. Exosomes: endosomal-derived vesicles shipping extracellular messages. Curr Opin Cell Biol. 2004;16(4):415-21.

19. Möbius W, Ohno-Iwashita Y, Donselaar EGV, Oorschot VM, Shimada $Y$, Fujimoto T, et al. Immunoelectron microscopic localization of cholesterol using biotinylated and non-cytolytic perfringolysin $\mathrm{O}$. J Histochem Cytochem. 2002;50(1):43-55.

20. Chen Q, Takada R, Noda C, Kobayashi S, Takada S. Different populations of Wnt-containing vesicles are individually released from polarized epithelial cells. Sci Rep. 2016:6(1):35562.

21. Valadi H, Ekström K, Bossios A, Sjöstrand M, Lee JJ, Lötvall JO. Exosome-mediated transfer of mRNAs and microRNAs is a novel mechanism of genetic exchange between cells. Nat Cell Biol. 2007;9(6):654-9.

22. Van Niel G, Porto-Carreiro I, Simoes S, Raposo G. Exosomes: a common pathway for a specialized function. J Biochem. 2006;140(1):13-21.

23. Poliakov A, Spilman M, Dokland T, Amling CL, Mobley JA. Structural heterogeneity and protein composition of exosome-like vesicles (prostasomes) in human semen. Prostate. 2009;69(2):159-67.

24. Minciacchi VR, Freeman MR, Di Vizio D. Extracellular vesicles in cancer: exosomes, microvesicles and the emerging role of large oncosomes. Semin Cell Dev Biol. 2015;40:41-51.

25. Mashouri L, Yousefi H, Aref AR, Ahadi AM, Molaei F, Alahari SK. Exosomes: composition, biogenesis, and mechanisms in cancer metastasis and drug resistance. Mol Cancer. 2019;18(1):75

26. Zarovni N, Corrado A, Guazzi P, Zocco D, Lari E, Radano G, et al. Integrated isolation and quantitative analysis of exosome shuttled proteins and nucleic acids using immunocapture approaches. Methods. 2015:87:46-58.

27. Rechavi O, Erlich Y, Amram H, Flomenblit L, Karginov FV, Goldstein I, et al. Cell contact-dependent acquisition of cellular and viral nonautonomously encoded small RNAs. Genes Dev. 2009;23(16):1971-9.

28. Doyle LM, Wang MZ. Overview of extracellular vesicles, their origin, composition, purpose, and methods for exosome isolation and analysis. Cells. 2019:8(7):727.

29. Zaborowski MP, Balaj L, Breakefield XO, Lai CP. Extracellular vesicles: composition, biological relevance, and methods of study. Bioscience. 2015;65(8):783-97.

30. Hessvik NP, Øverbye A, Brech A, Torgersen ML, Jakobsen IS, Sandvig K, et al. PIKfyve inhibition increases exosome release and induces secretory autophagy. Cell Mol Life Sci. 2016;73(24):4717-37.

31. Skotland T, Sandvig K, Llorente A. Lipids in exosomes: current knowledge and the way forward. Prog Lipid Res. 2017;66:30-41.

32. Kowal J, Arras G, Colombo M, Jouve M, Morath JP, Primdal-Bengtson $B$, et al. Proteomic comparison defines novel markers to characterize heterogeneous populations of extracellular vesicle subtypes. Proc Nat Acad Sci. 2016;113(8):E968-77.

33. Zeringer E, Barta T, Li M, Vlassov AV. Strategies for isolation of exosomes. Cold Spring Harbor Protoc. 2015;2015(4):074476.

34. Busatto S, Vilanilam G, Ticer T, Lin WL, Dickson DW, Shapiro S, et al. Tangential flow filtration for highly efficient concentration of extracellular vesicles from large volumes of fluid. Cells. 2018;7(12):273.

35. Pachler K, Lener T, Streif D, Dunai ZA, Desgeorges A, Feichtner M, et al. A Good Manufacturing Practice-grade standard protocol for exclusively human mesenchymal stromal cell-derived extracellular vesicles. Cytotherapy. 2017;19(4):458-72.

36. Andriolo G, Provasi E, Lo Cicero V, Brambilla A, Soncin S, Torre T, et al. Exosomes from human cardiac progenitor cells for therapeutic applications: development of a GMP-Grade Manufacturing Method. Front Physiol. 2018;9:1169.

37. Escudier B, Dorval T, Chaput N, André F, Caby M-P, Novault S, et al. Vaccination of metastatic melanoma patients with autologous dendritic cell
(DC) derived-exosomes: results of thefirst phase I clinical trial. J Trans| Med. 2005a;3(1):10.

38. Lamparski HG, Metha-Damani A, Yao JY, Patel S, Hsu DH, Ruegg C, et al. Production and characterization of clinical grade exosomes derived from dendritic cells. J Immunol Methods. 2002;270(2):211-26.

39. Zhang M, Jin K, Gao L, Zhang Z, Li F, Zhou F, et al. Methods and technologies for exosome isolation and characterization. Small Methods. 2018;2(9):1800021.

40. Van Deun J, Mestdagh P, Sormunen R, Cocquyt V, Vermaelen K Vandesompele J, et al. The impact of disparate isolation methods for extracellular vesicles on downstream RNA profiling. J Extracell Vesicles. 2014;3(1):24858.

41. Li P, Kaslan M, Lee SH, Yao J, Gao Z. Progress in exosome isolation techniques. Theranostics. 2017;7(3):789-804.

42. Dai S, Wei D, Wu Z, Zhou X, Wei X, Huang H, et al. Phase I clinical trial of autologous ascites-derived exosomes combined with GM-CSF for colorectal cancer. Mol Ther. 2008;16(4):782-90.

43. Morse MA, Garst J, Osada T, Khan S, Hobeika A, Clay TM, et al. A phase I study of dexosome immunotherapy in patients with advanced nonsmall cell lung cancer. J Transl Med. 2005;3(1):9.

44. Serwer P. Bacteriophages: separation of. In: Wilson ID, editor. Encyclopedia of Separation Science. Oxford: Academic Press; 2000. p. 2102-9.

45. Hameed BS, Bhatt CS, Nagaraj B, Suresh AK. Chapter 19-chromatography as an efficient technique for the separation of diversified nanoparticles. In: Hussain CM, editor. Nanomaterials in chromatography. Amsterdam: Elsevier; 2018. p. 503-18.

46. Carmignac DF. Biological centrifugation. Cell Biochem Func. 2002;20(4):357

47. Besse B, Charrier M, Lapierre V, Dansin E, Lantz O, Planchard D, et al. Dendritic cell-derived exosomes as maintenance immunotherapy after first line chemotherapy in NSCLC. Oncoimmunology. 2016;5(4):e1071008

48. Heinemann ML, Ilmer M, Silva LP, Hawke DH, Recio A, Vorontsova MA, et al. Benchtop isolation and characterization of functional exosomes by sequential filtration. J Chromatogr A. 2014;1371:125-35.

49. Escudier B, Dorval T, Chaput N, André F, Caby M-P, Novault S, et al. Vaccination of metastatic melanoma patients with autologous dendritic cell (DC) derived-exosomes: results of the first phase I clinical trial. J Transl Med. 2005b;3(1):10.

50. Bian S, Zhang L, Duan L, Wang X, Min Y, Yu H. Extracellular vesicles derived from human bone marrow mesenchymal stem cells promote angiogenesis in a rat myocardial infarction model. J Mol Med. 2014;92(4):387-97.

51. Lee C, Mitsialis SA, Aslam M, Vitali SH, Vergadi E, Konstantinou G, et al. Exosomes mediate the cytoprotective action of mesenchymal stromal cells on hypoxia-induced pulmonary hypertension. Circulation. 2012;126(22):2601-11.

52. Kang K, Ma R, Cai W, Huang W, Paul C, Liang J, et al. Exosomes secreted from CXCR4 overexpressing mesenchymal stem cells promote cardioprotection via Akt signaling pathway following myocardial infarction. Stem Cells Int. 2015;2015:659890.

53. Teng X, Chen L, Chen W, Yang J, Yang Z, Shen Z. Mesenchymal stem cell-derived exosomes improve the microenvironment of infarcted myocardium contributing to angiogenesis and anti-inflammation. Cell Physiol Biochem. 2015;37(6):2415-24.

54. Rezaie J, Rahbarghazi R, Pezeshki M, Mazhar M, Yekani F, Khaksar M, et al. Cardioprotective role of extracellular vesicles: a highlight on exosome beneficial effects in cardiovascular diseases. J Cell Physiol. 2019;234(12):21732-45.

55. Feng $Y$, Huang W, Wani M, Yu X, Ashraf M. Ischemic preconditioning potentiates the protective effect of stem cells through secretion of exosomes by targeting Mecp2 via miR-22. PLoS ONE. 2014;9(2):e88685.

56. Yu B, Gong M, Wang Y, Millard RW, Pasha Z, Yang Y, et al. Cardiomyocyte protection by GATA-4 gene engineered mesenchymal stem cells is partially mediated by translocation of miR-221 in microvesicles. PLoS ONE. 2013:8(8):e73304.

57. Yu B, Kim HW, Gong M, Wang J, Millard RW, Wang Y, et al. Exosomes secreted from GATA-4 overexpressing mesenchymal stem cells serve as a reservoir of anti-apoptotic microRNAs for cardioprotection. Int J Cardiol. 2015;182:349-60. 
58. Wang $N$, Chen C, Yang D, Liao Q, Luo H, Wang X, et al. Mesenchymal stem cells-derived extracellular vesicles, via miR-210, improve infarcted cardiac function by promotion of angiogenesis. Biochim Biophys Acta. 2017;1863(8):2085-92.

59. Wang K, Jiang Z, Webster KA, Chen J, Hu H, Zhou Y, et al. Enhanced cardioprotection by human endometrium mesenchymal stem cells driven by exosomal microRNA-21. Stem Cells TransI Med. 2017;6(1):209-22.

60. Zhang Z, Yang J, Yan W, Li Y, Shen Z, Asahara T. Pretreatment of Cardiac Stem Cells With Exosomes Derived From Mesenchymal Stem Cells Enhances Myocardial Repair. J Am Heart Assoc. 2016;5(1):28565.

61. Bruno S, Tapparo M, Collino F, Chiabotto G, Deregibus MC, Soares Lindoso $R$, et al. Renal regenerative potential of different extracellular vesicle populations derived from bone marrow mesenchymal stromal cells. Tissue Eng Part A. 2017;23(21-22):1262-73.

62. Chen L, Wang Y, Li S, Zuo B, Zhang X, Wang F, et al. Exosomes derived from GDNF-modified human adipose mesenchymal stem cells ameliorate peritubular capillary loss in tubulointerstitial fibrosis by activating the SIRT1/eNOS signaling pathway. Theranostics. 2020;10(20):9425-42.

63. Gatti S, Bruno S, Deregibus MC, Sordi A, Cantaluppi V, Tetta C, et al. Microvesicles derived from human adult mesenchymal stem cells protect against ischaemia-reperfusion-induced acute and chronic kidney injury. Nephrol Dial Transpl. 2011;26(5):1474-83.

64. Ranghino A, Bruno S, Bussolati B, Moggio A, Dimuccio V, Tapparo M, et al. The effects of glomerular and tubular renal progenitors and derived extracellular vesicles on recovery from acute kidney injury. Stem Cell Res Ther. 2017;8(1):24.

65. Choi HY, Moon SJ, Ratliff BB, Ahn SH, Jung A, Lee M, et al. Microparticles from kidney-derived mesenchymal stem cells act as carriers of proangiogenic signals and contribute to recovery from acute kidney injury. PLOS ONE. 2014;9(2):e87853.

66. Lin KC, Yip HK, Shao PL, Wu SC, Chen KH, Chen YT, et al. Combination of adipose-derived mesenchymal stem cells (ADMSC) and ADMSCderived exosomes for protecting kidney from acute ischemia-reperfusion injury. Int J Cardiol. 2016;216:173-85.

67. Reis LA, Borges FT, Simões MJ, Borges AA, Sinigaglia-Coimbra R, Schor N. Bone marrow-derived mesenchymal stem cells repaired but did not prevent gentamicin-induced acute kidney injury through paracrine effects in rats. PLoS ONE. 2012;7(9):e44092.

68. Zhang G, Zou X, Miao S, Chen J, Du T, Zhong L, et al. The anti-oxidative role of micro-vesicles derived from human Wharton-Jelly mesenchymal stromal cells through NOX2/gp91 (phox) suppression in alleviating renal ischemia-reperfusion injury in rats. PLoS ONE. 2014;9(3):e92129.

69. Zhang G, Zou X, Huang Y, Wang F, Miao S, Liu G, et al. Mesenchymal stromal cell-derived extracellular vesicles protect against acute kidney injury through anti-oxidation by enhancing Nrf2/ARE activation in rats. Kidney Blood Press Res. 2016;41(2):119-28.

70. Wang B, Jia H, Zhang B, Wang J, Ji C, Zhu X, et al. Pre-incubation with hucMSC-exosomes prevents cisplatin-induced nephrotoxicity by activating autophagy. Stem Cell Res Ther. 2017:8(1):75.

71. Zhou Y, Xu H, Xu W, Wang B, Wu H, Tao Y, et al. Exosomes released by human umbilical cord mesenchymal stem cells protect against cisplatin-induced renal oxidative stress and apoptosis in vivo and in vitro. Stem Cell Res Ther. 2013:4(2):34.

72. Tomasoni S, Longaretti L, Rota C, Morigi M, Conti S, Gotti E, et al. Transfer of growth factor receptor mRNA via exosomes unravels the regenerative effect of mesenchymal stem cells. Stem Cells Dev. 2013;22(5):772-80.

73. Li T, Yan Y, Wang B, Qian H, Zhang X, Shen L, et al. Exosomes derived from human umbilical cord mesenchymal stem cells alleviate liver fibrosis. Stem Cells Dev. 2013;22(6):845-54.

74. Tan CY, Lai RC, Wong W, Dan YY, Lim SK, Ho HK. Mesenchymal stem cellderived exosomes promote hepatic regeneration in drug-induced liver injury models. Stem Cell Res Ther. 2014;5(3):76.

75. Hyun J, Wang S, Kim J, Kim GJ, Jung Y. MicroRNA125b-mediated Hedgehog signaling influences liver regeneration by chorionic plate-derived mesenchymal stem cells. Sci Rep. 2015;5:14135.

76. Lou G, Yang Y, Liu F, Ye B, Chen Z, Zheng M, et al. MiR-122 modification enhances the therapeutic efficacy of adipose tissue-derived mesenchymal stem cells against liver fibrosis. J Cell Mol Med. 2017;21(11):2963-73.
77. Tamura R, Uemoto S, Tabata Y. Immunosuppressive effect of mesenchymal stem cell-derived exosomes on a concanavalin A-induced liver injury model. Inflamm Regen. 2016;36:26.

78. Yan Y, Jiang W, Tan Y, Zou S, Zhang H, Mao F, et al. hucMSC exosomederived GPX1 is required for the recovery of hepatic oxidant injury. Mol Ther. 2017;25(2):465-79.

79. Haga H, Yan IK, Takahashi K, Matsuda A, Patel T. Extracellular vesicles from bone marrow-derived mesenchymal stem cells improve survival from lethal hepatic failure in mice. Stem Cells Transl Med. 2017;6(4):1262-72.

80. Doeppner TR, Herz J, Görgens A, Schlechter J, Ludwig A-K, Radtke S, et al. Extracellular vesicles improve post-stroke neuroregeneration and prevent postischemic immunosuppression. Stem Cell Transl Med. 2015;4(10):1131-43.

81. Xin H, Li Y, Cui Y, Yang JJ, Zhang ZG, Chopp M. Systemic administration of exosomes released from mesenchymal stromal cells promote functional recovery and neurovascular plasticity after stroke in rats. J Cereb Blood Flow Metab. 2013;33(11):1711-5.

82. Xin H, LiY, Liu Z, Wang X, Shang X, Cui Y, et al. MiR-133b promotes neural plasticity and functional recovery after treatment of stroke with multipotent mesenchymal stromal cells in rats via transfer of exosomeenriched extracellular particles. Stem Cells. 2013;31(12):2737-46.

83. Xin H, Katakowski M, Wang F, Qian JY, Liu XS, Ali MM, et al. MicroRNA cluster miR-17-92 cluster in exosomes enhance neuroplasticity and functional recovery after stroke in rats. Stroke. 2017;48(3):747-53.

84. Drommelschmidt K, Serdar M, Bendix I, Herz J, Bertling F, Prager S, et al. Mesenchymal stem cell-derived extracellular vesicles ameliorate inflammation-induced preterm brain injury. Brain Behav Immun. 2017:60:220-32.

85. Ophelders DRMG, Wolfs TGAM, Jellema RK, Zwanenburg A, Andriessen P, Delhaas T, et al. Mesenchymal stromal cell-derived extracellular vesicles protect the fetal brain after hypoxia-ischemia. Stem Cells Transl Med. 2016;5(6):754-63.

86. Zhang Y, Chopp M, Meng Y, Katakowski M, Xin H, Mahmood A, et al. Effect of exosomes derived from multipluripotent mesenchymal stromal cells on functional recovery and neurovascular plasticity in rats after traumatic brain injury. J Neurosurg. 2015;122(4):856-67.

87. Ni H, Yang S, Siaw-Debrah F, Hu J, Wu K, He Z, et al. Exosomes derived from bone mesenchymal stem cells ameliorate early inflammatory responses following traumatic brain injury. Front Neurosci. 2019;13:14

88. Lankford KL, Arroyo EJ, Nazimek K, Bryniarski K, Askenase PW, Kocsis JD. Intravenously delivered mesenchymal stem cell-derived exosomes target M2-type macrophages in the injured spinal cord. PLOS ONE. 2018;13(1):e0190358.

89. Wang L, Pei S, Han L, Guo B, Li Y, Duan R, et al. Mesenchymal stem cell-derived exosomes reduce $\mathrm{A} 1$ astrocytes via downregulation of phosphorylated NFKB P65 subunit in spinal cord injury. Cell Physiol Biochem. 2018;50(4):1535-59.

90. Ruppert KA, Nguyen TT, Prabhakara KS, Toledano Furman NE, Srivastava AK, Harting MT, et al. Human mesenchymal Stromal cell-derived extracellular vesicles modify microglial response and improve clinical outcomes in experimental spinal cord injury. Sci Rep. 2018;8(1):480.

91. Cui GH, Wu J, Mou FF, Xie WH, Wang FB, Wang QL, et al. Exosomes derived from hypoxia-preconditioned mesenchymal stromal cells ameliorate cognitive decline by rescuing synaptic dysfunction and regulating inflammatory responses in APP/PS1 mice. FASEB J. 2018;32(2):654-68.

92. Katsuda T, Tsuchiya R, Kosaka N, Yoshioka Y, Takagaki K, Oki K, et al. Human adipose tissue-derived mesenchymal stem cells secrete functional neprilysin-bound exosomes. Sci Rep. 2013;3:1197.

93. Jarmalavičiūtè A, Tunaitis V, Pivoraitè U, Venalis A, Pivoriūnas A. Exosomes from dental pulp stem cells rescue human dopaminergic neurons from 6-hydroxy-dopamine-induced apoptosis. Cytotherapy. 2015;17(7):932-9.

94. Zhang B, Wu X, Zhang X, Sun Y, Yan Y, Shi H, et al. Human umbilical cord mesenchymal stem cell exosomes enhance angiogenesis through the Wnt4/ß-catenin pathway. Stem Cells Transl Med. 2015;4(5):513-22.

95. Fang S, Xu C, Zhang Y, Xue C, Yang C, Bi H, et al. Umbilical cord-derived mesenchymal stem cell-derived exosomal microRNAs suppress myofibroblast differentiation by inhibiting the transforming growth 
factor- $\beta / S M A D 2$ pathway during wound healing. Stem Cells TransI Med. 2016;5(10):1425-39.

96. Hu GW, Li Q, Niu X, Hu B, Liu J, Zhou SM, et al. Exosomes secreted by human-induced pluripotent stem cell-derived mesenchymal stem cells attenuate limb ischemia by promoting angiogenesis in mice. Stem Cell Res Ther. 2015;6(1):10.

97. Zhang B, Wang M, Gong A, Zhang X, Wu X, Zhu Y, et al. HucMSCexosome mediated-Wnt4 signaling is required for cutaneous wound healing. Stem Cells. 2015;33(7):2158-68.

98. Li X, Liu L, Yang J, Yu Y, Chai J, Wang L, et al. Exosome derived from human umbilical cord mesenchymal stem cell mediates MiR-181c attenuating burn-induced excessive inflammation. EBioMedicine. 2016;8:72-82.

99. Liang X, Zhang L, Wang S, Han Q, Zhao RC. Exosomes secreted by mesenchymal stem cells promote endothelial cell angiogenesis by transferring miR-125a. J Cell Sci. 2016;129(11):2182-9.

100. Zhang J, Guan J, Niu X, Hu G, Guo S, Li Q, et al. Exosomes released from human induced pluripotent stem cells-derived MSCs facilitate cutaneous wound healing by promoting collagen synthesis and angiogenesis. J Transl Med. 2015;13:49.

101. Shabbir A, Cox A, Rodriguez-Menocal L, Salgado M, Van Badiavas E. Mesenchymal stem cell exosomes induce proliferation and migration of normal and chronic wound fibroblasts, and enhance angiogenesis in vitro. Stem Cells Dev. 2015;24(14):1635-47.

102. Willis GR, Fernandez-Gonzalez A, Anastas J, Vitali SH, Liu X, Ericsson M, et al. Mesenchymal stromal cell exosomes ameliorate experimental bronchopulmonary dysplasia and restore lung function through macrophage immunomodulation. Am J Respir Crit Care Med. 2018;197(1):104-16

103. Cho BS, Kim JO, Ha DH, Yi YW. Exosomes derived from human adipose tissue-derived mesenchymal stem cells alleviate atopic dermatitis. Stem Cell Res Ther. 2018;9(1):187.

104. Nakamura Y, Miyaki S, Ishitobi H, Matsuyama S, Nakasa T, Kamei N, et al. Mesenchymal-stem-cell-derived exosomes accelerate skeletal muscle regeneration. FEBS Lett. 2015;589(11):1257-65.

105. Riazifar M, Mohammadi MR, Pone EJ, Yeri A, Lässer C, Segaliny Al, et al. Stem cell-derived exosomes as nanotherapeutics for autoimmune and neurodegenerative disorders. ACS Nano. 2019;13(6):6670-88.

106. Squillaro T, Peluso G, Galderisi U. Clinical trials with mesenchymal stem cells: an update. Cell Transpl. 2016;25(5):829-48.

107. Lou G, Chen Z, Zheng M, Liu Y. Mesenchymal stem cell-derived exosomes as a new therapeutic strategy for liver diseases. Exp Mol Med. 2017;49(6):e346.

108. Börger V, Bremer M, Ferrer-Tur R, Gockeln L, Stambouli O, Becic A, et al. Mesenchymal stem/stromal cell-derived extracellular vesicles and their potential as novel immunomodulatory therapeutic agents. Int J Mol Sci. 2017;18(7):1450
109. Kordelas L, Rebmann V, Ludwig AK, Radtke S, Ruesing J, Doeppner TR, et al. MSC-derived exosomes: a novel tool to treat therapy-refractory graft-versus-host disease. Leukemia. 2014;28(4):970-3.

110. Nassar W, El-Ansary M, Sabry D, Mostafa MA, Fayad T, Kotb E, et al. Umbilical cord mesenchymal stem cells derived extracellular vesicles can safely ameliorate the progression of chronic kidney diseases. Biomater Res. 2016;20:21.

111. Filho DM, de Carvalho RP, Oliveira LF, dos Santos ALRT, Parreira RC, Pinto MCX, et al. Enhancing the therapeutic potential of mesenchymal stem cells with the CRISPR-Cas system. Stem Cell Rev Rep. 2019;15(4):463-73.

112. Kim S, Kim TM. Generation of mesenchymal stem-like cells for producing extracellular vesicles. World J Stem Cells. 2019;11(5):270-80.

113. Théry C, Amigorena S, Raposo G, Clayton A. Isolation and characterization of exosomes from cell culture supernatants and biological fluids. Curr Protoc Cell Biol. 2006. https://doi.org/10.1002/0471143030.cb032 2s30.

114. Livshits MA, Khomyakova E, Evtushenko EG, Lazarev VN, Kulemin NA, Semina SE, et al. Correction: corrigendum: isolation of exosomes by differential centrifugation: theoretical analysis of a commonly used protocol. Sci Rep. 2016;6(1):21447.

115. Fatemeh M-H, Leonora B, Sara A, Pierre-Yves M, Allison EH, Alexander JT, et al. Current methods for the isolation of extracellular vesicles. Biol Chem. 2013;394(10):1253-62.

116. Cvjetkovic A, Lötvall J, Lässer C. The influence of rotor type and centrifugation time on the yield and purity of extracellular vesicles. J Extracell Vesicles. 2014;3(1):23111.

117. Abramowicz A, Widlak P, Pietrowska M. Proteomic analysis of exosomal cargo: the challenge of high purity vesicle isolation. Mol BioSyst. 2016;12(5):1407-19.

118. Salih M, Zietse R, Hoorn EJ. Urinary extracellular vesicles and the kidney: biomarkers and beyond. Am J Physiol Renal Physiol. 2014;306(11):F1251-9.

119. Taylor DD, Shah S. Methods of isolating extracellular vesicles impact down-stream analyses of their cargoes. Methods. 2015;87:3-10.

120. Lobb RJ, Becker M, Wen Wen S, Wong CS, Wiegmans AP, Leimgruber A, et al. Optimized exosome isolation protocol for cell culture supernatant and human plasma. J Extracell Vesicles. 2015;4(1):27031.

121. Gerlach JQ, Krüger A, Gallogly S, Hanley SA, Hogan MC, Ward CJ, et al. Surface glycosylation profiles of urine extracellular vesicles. PLOS ONE. 2013;8(9):e74801.

\section{Publisher's Note}

Springer Nature remains neutral with regard to jurisdictional claims in published maps and institutional affiliations.

Ready to submit your research? Choose BMC and benefit from:

- fast, convenient online submission

- thorough peer review by experienced researchers in your field

- rapid publication on acceptance

- support for research data, including large and complex data types

- gold Open Access which fosters wider collaboration and increased citations

- maximum visibility for your research: over $100 \mathrm{M}$ website views per year

At BMC, research is always in progress.

Learn more biomedcentral.com/submissions 